Review Article

\title{
Chinese Herbal Compounds for the Prevention and Treatment of Atherosclerosis: Experimental Evidence and Mechanisms
}

\author{
Qing Liu, ${ }^{1,2}$ Jianping Li, ${ }^{1}$ Adam Hartstone-Rose, ${ }^{1}$ Jing Wang, ${ }^{2}$ Jiqiang Li, ${ }^{2}$ \\ Joseph S. Janicki, ${ }^{1}$ and Daping Fan ${ }^{1}$ \\ ${ }^{1}$ Department of Cell Biology and Anatomy, University of South Carolina School of Medicine, 6439 Garners Ferry Road, \\ Columbia, SC 29208, USA \\ ${ }^{2}$ Guangdong Provincial Hospital of Chinese Medicine, The Second Clinical School of Medicine, \\ Guangzhou University of Chinese Medicine, Guangzhou 510405, China
}

Correspondence should be addressed to Daping Fan; daping.fan@uscmed.sc.edu

Received 19 August 2014; Accepted 15 October 2014

Academic Editor: Qunhao Zhang

Copyright (C) 2015 Qing Liu et al. This is an open access article distributed under the Creative Commons Attribution License, which permits unrestricted use, distribution, and reproduction in any medium, provided the original work is properly cited.

\begin{abstract}
Atherosclerosis is a leading cause of disability and death worldwide. Research into the disease has led to many compelling hypotheses regarding the pathophysiology of atherosclerotic lesion formation and the resulting complications such as myocardial infarction and stroke. Herbal medicine has been widely used in China as well as other Asian countries for the treatment of cardiovascular diseases for hundreds of years; however, the mechanisms of action of Chinese herbal medicine in the prevention and treatment of atherosclerosis have not been well studied. In this review, we briefly describe the mechanisms of atherogenesis and then summarize the research that has been performed in recent years regarding the effectiveness and mechanisms of antiatherogenic Chinese herbal compounds in an attempt to build a bridge between traditional Chinese medicine and cellular and molecular cardiovascular medicine.
\end{abstract}

\section{Introduction}

Atherosclerosis is a disease of the arterial wall that occurs at susceptible sites in major arteries. It is initiated by endothelial injury and subsequent lipid retention and oxidation in the intima which then provokes chronic inflammation and ultimately causes stenosis or thrombosis [1]. During this progression, residential arterial wall cells including endothelial cells (ECs) and vascular smooth muscle cells (VSMCs), as well as circulating leukocytes, especially monocytes/macrophages, are mainly involved. Atherosclerotic lesions can cause stenosis with potentially lethal distal ischemia or, if ruptured, can trigger thrombotic occlusion of major arteries to the heart, brain, legs, and other organs [2]. A variety of risk factors may intensify or provoke atherosclerosis through their effects on endothelial function, low-density lipoprotein (LDL) concentration and modification, and vascular wall inflammation. These risk factors include hypertension, smoking, diabetes mellitus, obesity, and bacterial infection [3].
Traditional Chinese medicine (TCM), especially herbal medicine, has been used for the treatment of cardiovascular diseases for hundreds of years as documented in Inner Canon of Yellow Emperor and Synopsis of Golden Chamber. Also, the effectiveness of several extracts derived from Chinese herbs has been evaluated in recent years. However, the cellular and molecular details regarding the underlying efficacious mechanisms of Chinese herbal medicine in treating atherosclerosis have just begun to be understood. Therefore, the purpose of this review is to first provide a brief description of the mechanisms of atherogenesis and then to summarize the recent research results regarding the effectiveness and mechanisms of antiatherogenic Chinese herbal compounds.

\section{Mechanisms of Atherogenesis}

Atherogenesis is an inflammatory process, initiated by the retention of lipids in the subendothelial space of the vascular wall and encompasses a complex interaction among the 
modified lipoproteins, residential vascular cells, and immune system [4]. The schematic in Figure 1 depicts the main steps of atherogenesis. In the following section, the main elements involved in the pathogenesis of atherosclerosis will be briefly described.

2.1. Hyperlipidemia. Dyslipidemia is one of the main risk factors leading to atherosclerosis [5]. The lipid hypothesis of atherogenesis states that abnormally elevated levels of plasma LDL and low levels of plasma high density lipoproteins (HDL) are the primary causes of atherosclerosis [6-8]. This hypothesis has been strongly supported by the success of statin drug therapy, which has significantly reduced coronary artery disease mortality through lowering plasma LDL levels during the past 40 years [9]. However, the HDL wing of the hypothesis remains to be confirmed by successful HDLtargeting approaches. A common mechanism through which hyperlipidemia causes atherosclerosis involves the accumulation of cholesteryl esters in macrophages of the arterial wall [10].

2.2. Endothelial Injury. The response-to-injury hypothesis of atherogenesis states that endothelial injury triggers subsequent interactions among all of the cells found in the atherosclerosis lesions [11]. Injured endothelium allows lipoproteins to migrate into subendothelial space. This, together with the discovery of adhesion molecules expressed by endothelial cells (e.g., vascular cell adhesion molecule-1), provides important insight into the initiation of atherosclerotic lesions [12]. That is, increased expression of adhesion molecules favors monocyte adhesion and penetration, which results in accumulation of macrophages within the subendothelial space where they encounter lipoprotein particles [13].

2.3. LDL Subendothelial Retention and Oxidation. Subendothelial retention of lipoproteins is a key early step in atherosclerosis, provoking a cascade of adverse events to the pathogenic response [14]. High levels of plasma lipids, particularly LDL and very-low density lipoproteins (VLDL), are among the pathophysiologic stimuli that induce endothelial dysfunction. Retention and modification of apolipoprotein B (apoB) containing lipoproteins, LDL, intermediate density lipoprotein (IDL), and lipoprotein (a) $[\operatorname{Lp}(a)]$ in the arterial intima extracellular matrix (ECM) represent early events of plaque development, which is referred to as the "responseto-retention" hypothesis [15].

The oxidation hypothesis of atherosclerosis suggests that an early event in the development of atherosclerosis is an oxidative modification of LDL that significantly increases its uptake into the arterial intima [16, 17]. Moreover, lipid overload may increase lipopolysaccharide (LPS) circulating levels and oxidative stress. In particular, the oxidation of lipoproteins that results from an imbalance of the pro- and antioxidant equilibrium is involved in the pathologic process of atherosclerotic alterations of cellular function. Lipid oxidation, induced by leukocyte-derived reactive oxygen species, not only promotes the growth and migration of smooth muscle cells, monocytes/macrophages, and fibroblasts, but also amplifies foam cell formation through oxidized LDL (oxLDL) formation and uptake [18].

2.4. Monocyte Migration and Activation. The overexpression of inducible adhesion molecules results in the adherence of mononuclear cells to the endothelial surface whereupon they receive chemoattractant signals that beckon them to enter the intima. With regard to the mechanisms that mediate monocyte-derived macrophage maturation, it has been reported that macrophage colony-stimulating factor (M-CSF) induces scavenger receptors and promotes the proliferation of monocytes in early atherosclerotic lesions [19]. Macrophages also contribute to the thrombotic complications of atherosclerosis in pivotal ways. These phagocytes furnish the bulk of the enzymes (i.e., matrix metalloproteinases, MMPs) that catabolize collagen, a key constituent of the fibrous cap of the plaque, which when activated predisposes the plaque to rupture [20].

2.5. Vascular Smooth Muscle Cell (VSMC) Migration and Proliferation. In response to atherogenic stimuli, VSMCs undergo a phenotypic switch from contractile phenotype to synthetic and inflammatory phenotype; the inflammatory VSMCs migrate into intima and proliferate, contributing to the atherogenesis $[21,22]$. VSMCs are the major producers of ECM within the vessel wall [23] and can modify the type of matrix proteins produced. In turn, the type of matrix present can affect the lipid content of the developing plaques and the proliferative index of the cells that are adherent to them. Like endothelial cells, VSMCs can also express a variety of adhesion molecules such as vascular cell adhesion molecule1 (VCAM-1) and intercellular adhesion molecule-1 (ICAM1) to which monocytes and lymphocytes can adhere and migrate into the vessel wall [24]. Like macrophages, VSMCs can also express a variety of receptors for lipid uptake and can form foam-like cells, thereby participating in the early accumulation of plaque lipid [25].

2.6. Foam Cell Formation. Foam cells mainly arise from mononuclear phagocytes, although smooth muscle and endothelial cells can also become engorged with lipids. Within the plaque, the mononuclear phagocytes express scavenger receptors (SRs), including CD36, SR-A, and SR-BI. These scavenger receptors mediate the engulfment of modified LDL particles that contribute to macrophage foam cell formation [26]. Other receptors for native lipoprotein particles, including LDLR, VLDLR, and LRP1, also contribute to foam cell formation. As mentioned above, VSMCs, which acquire a synthetic and inflammatory phenotype in the plaque, can also take up lipoproteins and transform into foam cells [27]. Death of foam cells leads to formation of a necrotic core, which serves as a depot for cellular debris and lipids [28].

\subsection{Apoptosis and Efferocytosis and Unresolved Inflammation.} As atherosclerotic lesions evolve, both the macrophagederived and smooth muscle-derived foam cells can undergo programmed cell death or apoptosis [29]. The death of foam 


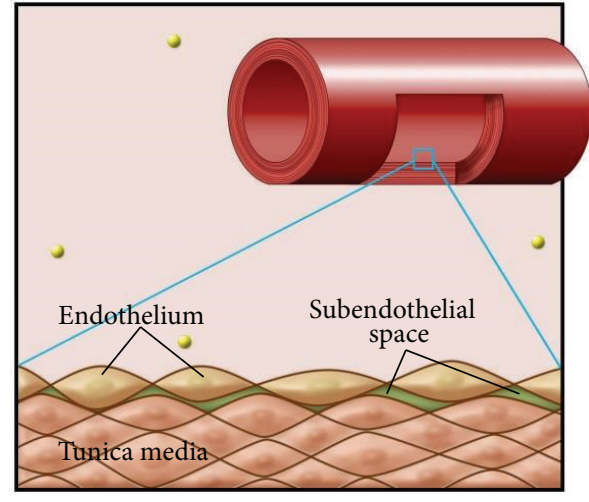

(a)

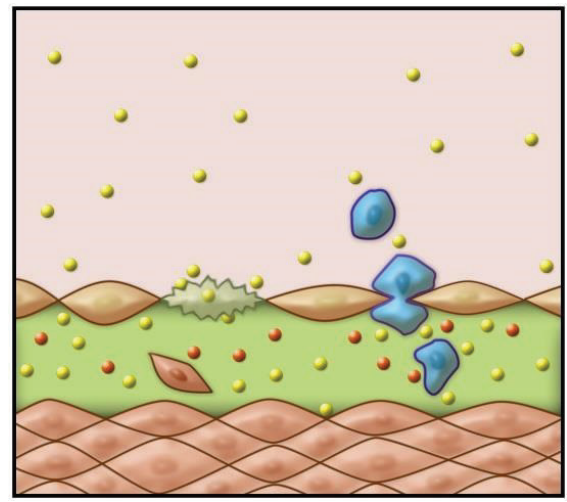

(c)

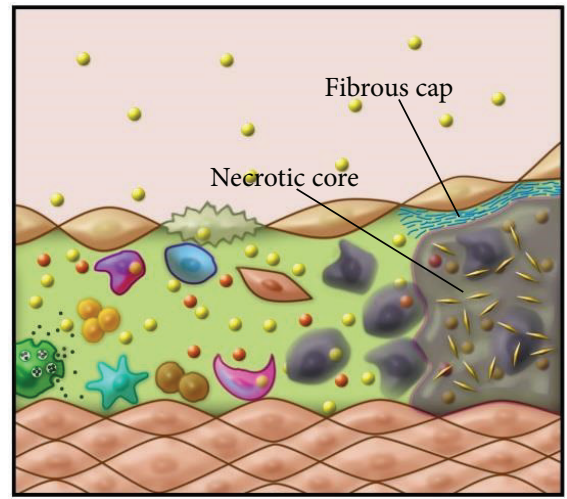

(e)
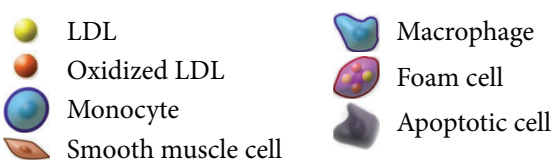

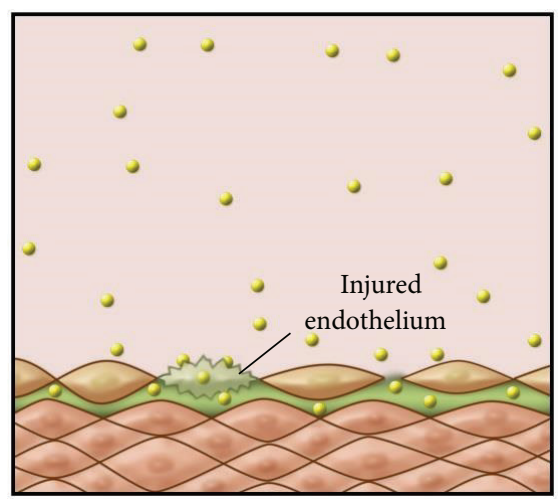

(b)

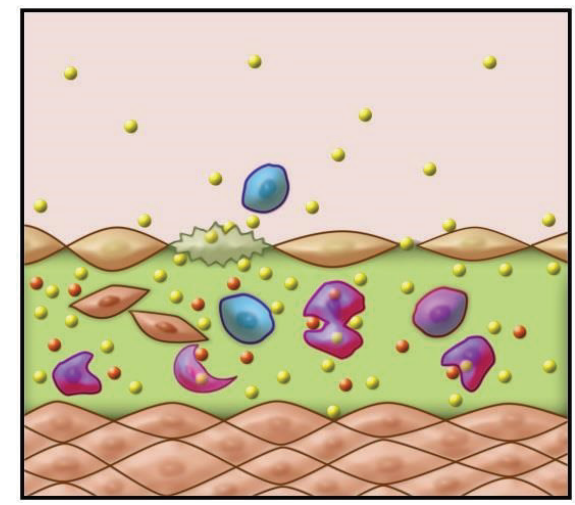

(d)

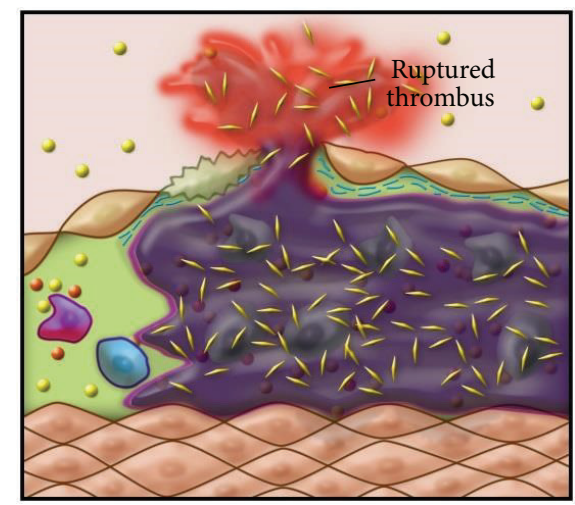

(f)

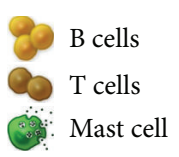

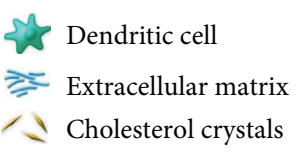

FIGURE 1: A schematic drawing depicting the formation of atherosclerotic plaques. (a) In the wall of a normal artery, there is a very small subendothelial space in the intima between the endothelium and the smooth muscle cell layer in tunica media. (b) Hyperlipidemia and endothelial injury lead to the infiltration of LDL particles into the subendothelial space. (c) A large number of LDL particles are retained and subsequently oxidized in the subendothelial space, followed by monocyte infiltration (from lumen) and smooth muscle cell migration (from tunica media). (d) Monocytes and smooth muscle cells differentiate into macrophages, which engulf LDL and turn into foam cells, and are activated by oxidized LDL. SMCs are also activated, proliferate, and transform into lipid-laden foam cells. (e) Macrophage and smooth muscle foam cells undergo apoptosis; unbalanced apoptosis/efferocytosis results in necrotic core formation and unresolved inflammation. Other immune cell types also participate in the arterial wall inflammation. (f) Erosion of the fibrous cap caused by the matrix degrading enzymes secreted by the macrophages leads to unstable plaques, which eventually rupture and result in thrombus formation and adverse clinical events. 
cells may not be a random event or the result of bursting like an overinflated balloon due to lipid overload. Rather, it may be due in part to gradients of concentration of factors such as macrophage colony-stimulating factor (M-CSF) required for survival of human monocytes [20]. However, some apoptotic cells may not disappear from the atherosclerotic lesions but instead accumulate in a "mummified" state [20]. The elegant studies of Ira Tabas have elaborated upon this concept of impaired clearance, or "efferocytosis", of apoptotic cells in plaques, which leads to unresolved inflammation [30]. The apoptotic foam cells that escape efferocytosis release their lipid content to the extracellular space and contribute to lipid core formation.

Over the last dozen years, appreciation of the role of inflammation in atherosclerosis has burgeoned. Intralesional or extralesional inflammation may hasten atheroma evolution and precipitate acute events. Circulating acute-phase reactants elicited by inflammation not only may serve as a biomarker for increased risk of vascular events, but also in some cases may contribute to their pathogenesis [31]. Advances stemming from basic research have established a fundamental role for inflammation in mediating all stages of this disease from initiation through progression and, ultimately, to the thrombotic complications of atherosclerosis.

The basic science of inflammatory biology applied to atherosclerosis has provided considerable insight into the mechanisms underlying the recruitment of leukocytes. Early after the initiation of atherogenesis, arterial endothelial cells begin to express on their surface selective adhesion molecules that bind various classes of leukocytes [12]. In particular, VCAM-1 binds precisely the types of leukocytes involved in early atheroma, the monocyte and T lymphocyte. Not only does VCAM-1 expression increase on endothelial cells overlying nascent atheroma, but defective VCAM-1 shows interrupted lesion development [32]. Once adhered to the endothelium, leukocytes penetrate into the intima in response to chemoattractant molecules. For example, monocyte chemoattractant protein-1 (MCP-1) appears responsible for the direct migration of monocytes into the intima at sites of lesion formation [33]. Once resident in the arterial wall, the blood-derived inflammatory cells participate in and perpetuate a local inflammatory response. The macrophages express scavenger receptors for modified lipoproteins, permitting them to ingest lipid and become foam cells. In addition to MCP-1, macrophage colony-stimulating factor (M-CSF) contributes to the differentiation of the blood monocyte into the macrophage foam cell [34]. T cells likewise encounter signals that cause them to elaborate inflammatory cytokines such as tumor necrosis factor- $\alpha$ (TNF- $\alpha$ ) that in turn can stimulate macrophages as well as vascular endothelial cells and SMCs [35]. As this inflammatory process continues, the activated leukocytes and intrinsic arterial cells can release fibrogenic mediators including a variety of peptide growth factors that can promote replication of SMCs and contribute to elaboration by these cells of a dense ECM characteristic of a more advanced atherosclerosis lesion. Inflammatory processes not only promote initiation and evolution of atheroma, but also contribute decisively to precipitating the acute thrombotic complications of atheroma [3]. The activated macrophages abundant in atheroma can produce proteolytic enzymes capable of degrading the collagen that lends strength to the plaque's protective fibrous cap, rendering the cap thin, weak, and susceptible to rupture. Inflammatory mediators regulate tissue factor expression by plaque macrophages, demonstrating an essential link between arterial inflammation and thrombosis [36].

Both innate and adaptive immunity are involved in atherosclerosis. Inflammation per se can drive arterial hyperplasia, even in the absence of traditional risk factors [37]. Cytokines as inflammatory messengers provide a mechanism whereby risk factors for atherosclerosis can alter arterial biology. Inflammation regulates aspects of plaque biology that trigger the thrombotic complications of atherosclerosis [38]. Overall, inflammatory mediators participate in all phases of atherogenesis, from lesion initiation through progression and ultimately to the clinical complications of this disease. The fact that all types of immune cells have been found in atherosclerotic plaques indicates that all immune components may participate in atherogenesis. All of these factors form the basis of the "inflammatory hypothesis."

\section{Effects and Mechanisms of Chinese Herb Compounds in the Attenuation of Atherosclerosis}

An early description of the clinical manifestations and treatment of atherosclerosis can be found in the classic traditional Chinese medicine book Inner Canon of Yellow Emperor, which was completed around 500 BC. In the theory of traditional Chinese medicine, atherosclerosis is usually referred to as "MaiBi," a vascular problem that is caused by $Q i$ stagnation, Blood stasis, and/or coagulated Phlegm, in which Qi stands for the energy, Blood stands for the material, and Phlegm stands for a kind of pathological product. For over two thousand years, atherosclerosis and its resulting heart disease have been treated with numerous herbal remedies. While somewhat effective, these herbal remedies have not been well studied using evidence-based approaches or using modern cellular and molecular techniques. Recently, however, investigations to examine the effects and mechanisms of single herbal compounds in the modulation of atherogenesis have occurred. A summary of these studies is presented in the following section wherein the compounds are discussed according to their site of activity.

\subsection{Chinese Herbal Compounds with Endothelial Protective} Activity (Table 1). The study by Lee et al. demonstrated that pretreatment of human umbilical vein endothelial cells (HUVEC) with Buddleja Officinalis (BO, 1-10 microg/mL) for 18 hrs dose-dependently inhibited TNF- $\alpha$-induced adhesion U937 monocytic cells as well as mRNA and protein expressions of VCAM-1 and ICAM-1. Pretreatment with $\mathrm{BO}$ also blocked TNF- $\alpha$-induced reactive oxygen species (ROS) formation. Nuclear factor-kappa B (NF-kappa B) is required for the transcription of these adhesion molecule genes [43]. Wan et al. found that Panax notoginseng saponins (PNS), derived from the Chinese herb Panax notoginseng, 
TABLE 1: Chinese herbal compounds with endothelial protective activity.

\begin{tabular}{|c|c|c|c|c|}
\hline Compound & Herb & Target or indicator & Type of study & Reference \\
\hline Resveratrol & $\begin{array}{l}\text { Rhizoma polygonum } \\
\text { cuspidatum }\end{array}$ & cav-1, VEGF, KDR & In vitro & [39] \\
\hline $\begin{array}{l}\text { Cynanchum } \\
\text { wilfordii }\end{array}$ & Cynanchum wilfordii & $\begin{array}{l}\text { LDL, HDL, NO, E-selectin, } \\
\text { VCAM-1, ICAM-1, ET-1 }\end{array}$ & In vivo & {$[40]$} \\
\hline $\begin{array}{l}\text { Protocatechuic } \\
\text { aldehyde }\end{array}$ & $\begin{array}{l}\text { Salvia miltiorrhiza } \\
\text { Bunge }\end{array}$ & $\begin{array}{l}\text { Caspase- } 3 \text {, caspase- } 2 \text {, Bcl- } 2 / \text { Bax, } \\
\text { cytochrome c, caspase- } 9 \text {, } \\
\text { granzyme B }\end{array}$ & In vitro & {$[41]$} \\
\hline Cryptotanshinone & $\begin{array}{l}\text { Salvia miltiorrhiza } \\
\text { Bunge }\end{array}$ & $\begin{array}{l}\text { oxLDL, NO, ICAM-1, VCAM-1; } \\
\text { monocyte adhesion }\end{array}$ & In vitro & {$[42]$} \\
\hline $\begin{array}{l}\text { Aqueous extract of } \\
\text { Buddleja officinalis }\end{array}$ & Buddleja officinalis & VCAM-1, ICAM-1; ROS; NF- $\kappa$ B & In vitro & {$[43]$} \\
\hline $\begin{array}{l}\text { Tribulus terrestris } \\
\text { extract }\end{array}$ & Tribulus terrestris & TC, HDL, LDL, TG & In vivo & {$[44]$} \\
\hline Panax notoginseng & $\begin{array}{l}\text { Panax notoginseng } \\
\text { saponins }\end{array}$ & ICAM-1 and VCAM-1 & In vivo & {$[45]$} \\
\hline $\begin{array}{l}\text { Ginkgo biloba } \\
\text { extract }\end{array}$ & Ginkgo biloba & $\begin{array}{l}\text { VCAM-1, ICAM-1, E-selectin; } \\
\text { ROS, RSTF }\end{array}$ & Both & {$[46,47]$} \\
\hline Salvia miltiorrhiza & $\begin{array}{l}\text { Salvia miltiorrhiza } \\
\text { Bunge }\end{array}$ & $\begin{array}{l}\text { eNOS, NO, NADPH oxidase } \\
\text { subunit Nox4 }\end{array}$ & In vitro & {$[48]$} \\
\hline Bisacurone & $\begin{array}{l}\text { Curcuma longa Linne } \\
\text { (Zingiberaceae) }\end{array}$ & VCAM-1, NF- $\kappa$ B p65, Akt, PKC & In vitro & {$[49]$} \\
\hline Magnolol & Magnolia officinalis & $\begin{array}{l}\text { IL-6, STAT3, Tyr705 and Ser727, } \\
\text { ICAM-1, IREs, monocyte } \\
\text { adhesion, cyclin D1, MCP-1, } \\
\text { NF-kB, VCAM-1 }\end{array}$ & Both & {$[50,51]$} \\
\hline $\begin{array}{l}\text { Aqueous extract of } \\
\text { Salvia miltiorrhiza }\end{array}$ & $\begin{array}{l}\text { Salvia miltiorrhiza } \\
\text { Bunge }\end{array}$ & ICAM-1, VCAM-1, GSH, NF- $\kappa$ B & In vitro & {$[52]$} \\
\hline Salvianolic acid B & $\begin{array}{l}\text { Salvia miltiorrhiza } \\
\text { Bunge }\end{array}$ & ICAM-1, E-selectin, NF- $\kappa$ B & In vitro & {$[53]$} \\
\hline
\end{tabular}

dose-dependently inhibited monocyte adhesion to activated endothelium, as well as the expression of TNF- $\alpha$-induced endothelial adhesion molecules, such as ICAM-1 and VCAM1 [45]. Recent findings reported by Tian et al. indicated that Resveratrol, a compound derived from the Chinese herb Rhizoma polygonum cuspidatum, downregulated the increased expressions of vascular endothelial growth factor (VEGF) and kinase insert domain receptor (KDR or VEGF receptor-2) [39]. Results from Choi et al. showed that extract from Cynanchum wilfordii (ECW) treatment significantly decreased vascular inflammation through an inhibition of cellular adhesion molecules such as E-selectin, VCAM-1, and ICAM-1 as well as endothelin-1 (ET-1) expression [40].

3.2. Chinese Herbal Compounds That Lower Lipids and Antioxidation (Tables 2 and 3). Zhang et al. [54] using a plasma lipid analysis approach found Celastrus orbiculatus Thunb Extract (COT), a compound derived from the Chinese herb Celastrus orbiculatus Thunb, to decrease total cholesterol (TC), non-high-density lipoprotein cholesterol (non-HDLC), triglyceride (TG), apolipoprotein B100 (apoB100), and apolipoprotein $\mathrm{E}$ (apoE) levels and to increase the level of HDL cholesterol (HDL-C). Quantitative real-time PCR revealed that COT upregulated the mRNA abundance of LDL receptor (LDL-R), scavenger receptor class B type 1 (SR-B1), cholesterol 7 $\alpha$-hydroxylase A1 (CYP7A1), and 3-hydroxy-3methyl-glutaryl-CoA reductase (HMGCR) [54]. Choi et al. reported that extract from the herb Cynanchum wilfordii treatment in HFCD-fed rats lessened LDL cholesterol and triglyceride levels and elevated HDL cholesterol [40]. Results from Subramaniam et al. indicated that the ethanolic fraction of the herb T. arjuna significantly decreased TC, LDL, and TG levels, increased HDL, and lessened the number of aortic atherosclerotic lesions [57]. Dinani et al. demonstrated the ability of the extract from the Chinese herb Artemisia aucheri to significantly reduce the levels of TC, LDL cholesterol, and TG and to increase HDL cholesterol [58].

Li et al. discovered that Farrerol, an extract from the Chinese herb Rhododendron dauricum L., significantly inhibited the $\mathrm{H}_{2} \mathrm{O}_{2}$-induced loss of cell viability and enhanced superoxide dismutase (SOD) and glutathione peroxidase (GSH-Px) activities in EA.hy926 cells. In addition, Farrerol inhibited the $\mathrm{H}_{2} \mathrm{O}_{2}$-induced elevation in the levels of intracellular malondialdehyde (MDA) and reactive oxygen species (ROS) [63]. Chen et al. reported that treatment with Salvianolic acid B (Sal B), a main compound derived from the herb Salvia miltiorrhiza Bunge, suppressed ERK1/2 and JNK phosphorylation and attenuated the increase in prostaglandin E2 production and NADPH oxidase activity in LPS-treated human aortic smooth muscle cells (HASMCs), indicating that 
TABLE 2: Chinese herbal compounds that lower lipids.

\begin{tabular}{|c|c|c|c|c|}
\hline Compound & Herb & Target or indicator & Type of study & Reference \\
\hline $\begin{array}{l}\text { Celastrus } \\
\text { orbiculatus Thunb. }\end{array}$ & $\begin{array}{l}\text { Celastrus orbiculatus } \\
\text { Thunb. }\end{array}$ & $\begin{array}{l}\text { TC, non-HDL, TG, apoB100, } \\
\text { apoE, HDL; LDL receptor, SR-B1, } \\
\text { CYP7A1, HMGCR, CRP, MDA }\end{array}$ & In vivo & {$[54]$} \\
\hline Salvianolic acid B & $\begin{array}{l}\text { Salvia Miltiorrhiza } \\
\text { Bunge }\end{array}$ & mLDL, CD36 & In vitro & {$[55]$} \\
\hline $\begin{array}{l}\text { Cynanchum } \\
\text { wilfordii }\end{array}$ & Cynanchum wilfordii & LDL, HDL, NO; Akt, & In vivo & {$[56]$} \\
\hline $\begin{array}{l}\text { Ethanolic fraction } \\
\text { of T. arjuna }\end{array}$ & Terminalia arjuna & LDL, TG, VLDL, HDL & In vivo & {$[57]$} \\
\hline Artemisia aucheri & Artemisia aucheri & $\begin{array}{l}\text { Total cholesterol, LDL } \\
\text { cholesterol, triglycerides, HDL } \\
\text { cholesterol }\end{array}$ & In vivo & {$[58]$} \\
\hline $\begin{array}{l}\text { Tribulus terrestris } \\
\text { extract }\end{array}$ & Tribulus terrestris & TC, HDL, LDL, TG & In vivo & {$[44]$} \\
\hline Ginsenosides & Panax spp. & $\begin{array}{l}\text { PPARs, total cholesterol, } \\
\text { triglyceride }\end{array}$ & In vivo & {$[59]$} \\
\hline Ocimum basilicum & Ocimum basilicum & $\begin{array}{l}\text { Total cholesterol, triglycerides, } \\
\text { LDL-cholesterol, } \\
\text { HDL-cholesterol }\end{array}$ & In vivo & {$[60]$} \\
\hline
\end{tabular}

Sal B has antioxidant properties [71]. Jia et al. showed that Tanshinone IIA (TSN IIA), another main compound derived from the Chinese herb Salvia Miltiorrhiza Bunge, markedly inhibited the elevation of ROS evoked by $\mathrm{H}_{2} \mathrm{O}_{2}$. Real time RT-PCR and Western blotting analysis demonstrated the ability of TSN IIA to significantly decrease the $\mathrm{H}_{2} \mathrm{O}_{2}$-induced expression of proapoptotic proteins Bax and caspase- 3 and to significantly increase the expression of antiapoptotic protein Bcl-2 in EA.hy926 cells [64].

Results from Xu et al. showed that the Lectin-like oxidized LDL (oxLDL) receptor-1 (LOX-1), a novel scavenger receptor highly expressed in human and experimental atherosclerotic lesions, is responsible for the uptake of oxLDL in vascular cells. oxLDL induced LOX-1 expression at the mRNA and protein levels, which was abrogated by the addition of Tanshinone IIA or a widely used inhibitor of NF- $\kappa \mathrm{B}$, suggesting the involvement of NF- $\kappa \mathrm{B}$ [65]. Hung et al. described that a low dose $(0.015 \mathrm{mg} / \mathrm{mL})$ of $S$. miltiorrhiza aqueous extract (SMAE), derived from the Chinese herb Salvia miltiorrhiza Bunge, significantly inhibited the growth of a rat smooth muscle cell line (A10) under Hcy stimulation, and the intracellular ROS concentration decreased after SMAE treatment in terms of reducing $\mathrm{p} 47$ (phox) translocation and increasing catalase activity. The signaling profile suggests that SMAE inhibited Hcy-induced A10 cell growth via the PKC/MAPKdependent pathway [68].

3.3. Chinese Herbal Compounds That Suppress Monocyte Migration and Activation (Table 4). Within plaque formation, activated endothelial cells increase the expression of adhesion molecules and inflammatory genes and circulating monocytes migrate into subendothelial space and differentiate into macrophages. In support of this concept, Chen et al. found that extract from Ginkgo biloba, a Chinese herb with antioxidant activity, could significantly suppress inflammatory cytokine-stimulated endothelial adhesiveness to human monocytic cells by attenuating intracellular ROS formation, redox-sensitive transcription factor activation, and VCAM-1 as well as ICAM-1 expression in human aortic endothelial cells [46]. Wan et al. found that Panax notoginseng saponins (PNS) dose-dependently inhibited monocyte adhesion on activated endothelium, as well as the expression of TNF- $\alpha$-induced endothelial adhesion molecules, such as ICAM-1 and VCAM-1 [45]. According to the report by Park, Prunella vulgaris ethanol extract inhibited adhesion of monocyte/macrophage-like THP-1 cells to the activated HASMCs [91]. The role of Curcumin, derived from the Chinese herb Curcuma longa, was shown by Wang et al. to have a sonodynamic effect on THP-1-derived macrophages and, therefore, to be a promising treatment for atherosclerosis [92]. Finally, Duan et al. identified Phyllanthus emblica extract as being able to prevent ECV-304 cells from adhering to monocytes [79].

3.4. Chinese Herbal Compounds That Suppress VSMC Migration and Proliferation (Table 5). Several lines of evidence exist to indicate the effectiveness of Chinese herbs on VSMC migration and proliferation. Moon et al. observed that Protocatechuic aldehyde (PCA), a compound derived from the Chinese herb Salvia miltiorrhiza Bunge, significantly attenuated PDGF-induced VSMC proliferation and migration at a pharmacologically relevant concentration $(100 \mu \mathrm{M})$. On a molecular level, they observed downregulation of the phosphatidylinositol 3-kinase (PI3 K)/Akt and the mitogenactivated protein kinase (MAPK) pathways, both of which are known to regulate key enzymes associated with migration and proliferation. Moreover, they found that PCA arrested the S-phase of the VSMC cell cycle and suppressed cyclin D2 expression [93]. Results from Kim et al. indicated that Corynoxeine, derived from the Chinese herb Hook of 
TABLE 3: Chinese herbal compounds with antioxidation activity.

\begin{tabular}{|c|c|c|c|c|}
\hline Compound & Herb & Target or indicator & Type of study & Reference \\
\hline $\begin{array}{l}\text { Arisaema tortuosum } \\
\text { tuber extract }\end{array}$ & Arisaema tortuosum Schott & $\beta$-Glucuronidase; FRAP & In vitro & {$[61]$} \\
\hline $\begin{array}{l}\text { Andrographolide } \\
\text { derivatives }\end{array}$ & Andrographolide & $\begin{array}{l}\text { VLDL-C, LDL-C, HDL-C; superoxide } \\
\text { anions, hydroxyl radicals }\end{array}$ & In vivo & {$[62]$} \\
\hline Farrerol & $\begin{array}{l}\text { Rhododendron dauricum L. } \\
\text { (ManShanHong) }\end{array}$ & SOD, GSH-Px; caspase-3, p38 MAPK, Bcl-2 & In vitro & {$[63]$} \\
\hline $\begin{array}{l}\text { Celastrus orbiculatus } \\
\text { Thunb. }\end{array}$ & Celastrus orbiculatus Thunb. & $\begin{array}{l}\text { TC, non-HDL, TG, apoB100, apoE, HDL; } \\
\text { LDL receptor, SR-B1, CYP7A1, HMGCR, } \\
\text { CRP, MDA }\end{array}$ & In vivo & {$[54]$} \\
\hline Tanshinone IIA & Salvia miltiorrhiza Bunge & $\begin{array}{l}\text { ROS, Bax/Bcl-2, caspase- } 3 \text {, LOX-1, NF- } \kappa \text { B, } \\
\text { oxLDL, monocyte adhesion, VSMC } \\
\text { migration and proliferation, macrophage } \\
\text { cholesterol accumulation, TNF- } \alpha \text {, TGF- } \beta 1 \text {, } \\
\text { platelet aggregation, GPx }\end{array}$ & Both & [64-67] \\
\hline Cryptotanshinone & Salvia miltiorrhiza Bunge & $\begin{array}{l}\text { oxLDL, NO, ICAM-1, VCAM-1; monocyte } \\
\text { adhesion }\end{array}$ & In vitro & {$[42]$} \\
\hline $\begin{array}{l}\text { Ethanolic fraction of } \\
\text { T. arjuna }\end{array}$ & Terminalia arjuna & LDL, TG, VLDL, HDL & In vivo & {$[57]$} \\
\hline $\begin{array}{l}\text { Salvia miltiorrhiza } \\
\text { aqueous extract }\end{array}$ & Salvia miltiorrhiza Bunge & Hcy, ROS; PKC/MAPK & In vivo & {$[68]$} \\
\hline $\begin{array}{l}\text { Chlorophytum } \\
\text { borivilianum root } \\
\text { extract }\end{array}$ & Chlorophytum borivilianum & $\begin{array}{l}\text { LDL oxidation, lipid hydroperoxides, } \\
\text { thiobarbituric acid }\end{array}$ & In vitro & {$[69]$} \\
\hline $\begin{array}{l}\text { Aqueous extract of } \\
\text { Buddleja officinalis }\end{array}$ & Buddleja officinalis & VCAM-1, ICAM-1; ROS; NF- $\kappa$ B & In vitro & {$[43]$} \\
\hline Salvianolic acid B & Salvia miltiorrhiza Bunge & $\begin{array}{l}\text { oxLDL, ROS, COX, ERK1/2, JNK, MAPK; } \\
\text { prostaglandin E2, NADPH oxidase, MMP-2, } \\
\text { MMP-9 }\end{array}$ & Both & {$[70-73]$} \\
\hline $\begin{array}{l}\text { Caffeoylquinic acids } \\
\text { (CQs) }\end{array}$ & Chwinamul & ROS & Both & {$[74]$} \\
\hline $\begin{array}{l}\text { Epimedium } \\
\text { (Berberidaceae) }\end{array}$ & Epimedium spp. & ROS & Both & {$[75]$} \\
\hline Goji & $\begin{array}{l}\text { Lycium barbarum and } L . \\
\text { chinense }\end{array}$ & SOD, MDA; JNK & Both & {$[76]$} \\
\hline Ginkgo biloba extract & Ginkgo biloba & VCAM-1, ICAM-1, E-selectin; ROS, RSTF & Both & {$[46]$} \\
\hline Salvia miltiorrhiza & Salvia miltiorrhiza Bunge & eNOS, NO, NADPH oxidase subunit Nox4 & In vitro & {$[48]$} \\
\hline $\begin{array}{l}\text { Scutellaria baicalensis } \\
\text { Georgi flavonoids }\end{array}$ & Scutellaria baicalensis Georgi & SOD & Both & {$[77]$} \\
\hline Emodin & Rheum rhabarbarum & ApoE, PPAR- $\gamma$, GM-CSF, MMP-9 & In vivo & {$[78]$} \\
\hline Bisacurone & $\begin{array}{l}\text { Curcuma longa Linne } \\
\text { (Zingiberaceae) }\end{array}$ & VCAM-1, NF- $\kappa$ B p65, Akt, PKC & In vitro & {$[49]$} \\
\hline $\begin{array}{l}\text { Phyllanthus emblica } \\
\text { extract }\end{array}$ & Phyllanthus emblica & ox-LDL, MDA & In vitro & {$[79]$} \\
\hline $\begin{array}{l}\text { Ethanol extract of } \\
\text { Glossogyne tenuifolia }\end{array}$ & Glossogyne tenuifolia & oxLDL, ROS & In vitro & {$[80]$} \\
\hline Ocimum basilicum & Ocimum basilicum & total cholesterol, triglycerides, LDL, HDL & In vivo & {$[60]$} \\
\hline Paeonol & Paeonia lactiflora Pallas & ICAM-1, NF- $\kappa$ B p 65 translocation, ERK, p38 & In vitro & {$[81]$} \\
\hline $\begin{array}{l}\text { Water extracts of } \\
\text { Achyrocline } \\
\text { satureoides }\end{array}$ & Achyrocline satureoides & LDL oxidation & In vitro & {$[82]$} \\
\hline Alaternin & Cassia tora & NO, Peroxynitrite & In vitro & {$[83]$} \\
\hline $\begin{array}{l}\text { Aqueous extract of } \\
\text { Salvia miltiorrhiza }\end{array}$ & Salvia miltiorrhiza Bunge & Hcy & In vitro & {$[84]$} \\
\hline
\end{tabular}


TABLE 3: Continued.

\begin{tabular}{lllll}
\hline Compound & Herb & Target or indicator & Type of study & Reference \\
\hline $\begin{array}{l}\text { Gypenosides } \\
\begin{array}{l}\text { Saponins } \\
\text { baicalein, baicalin and }\end{array}\end{array}$ & Gynostemma pentaphyllum & mitochondrial enzyme & In vitro & [85] \\
$\begin{array}{l}\text { wogonin } \\
\text { Scoparone }\end{array}$ & Artemisia scoparia & VSMC proliferation & In vitro & [86] \\
$\begin{array}{l}\text { Trilinolein } \\
\text { Celastrol }\end{array}$ & Panax pseudoginseng & monocyte adhesion, lipid laden foam cells & In vivo & In vitro \\
$\begin{array}{l}\text { Phenolic Rye (Secale } \\
\text { cereale L.) }\end{array}$ & Ferulic acid & oxLDL, LOX-1, ROS, iNOS, NO, TNF-a, & In vivo & [88] \\
\hline
\end{tabular}

TABLE 4: Chinese herbal compounds that suppress monocyte migration and activation.

\begin{tabular}{|c|c|c|c|c|}
\hline Compound & Herb & Target or indicator & Type of study & Reference \\
\hline $\begin{array}{l}\text { Prunella vulgaris } \\
\text { ethanol extract }\end{array}$ & Prunella vulgaris & $\begin{array}{l}\text { VCAM-1, ICAM-1, E-selectin, } \\
\text { ROS; p38 MAPK, ERK }\end{array}$ & In vitro & [91] \\
\hline Curcumin & Curcuma longa & $\begin{array}{l}\text { Macrophage morphological } \\
\text { changes }\end{array}$ & In vitro & {$[92]$} \\
\hline Panaxnotoginseng & $\begin{array}{l}\text { Panax notoginseng } \\
\text { saponins }\end{array}$ & ICAM-1 and VCAM-1 & In vivo & {$[45]$} \\
\hline Ginkgo biloba extract & Ginkgo biloba & $\begin{array}{c}\text { VCAM-1, ICAM-1, E-selectin; } \\
\text { ROS, RSTF }\end{array}$ & Both & {$[46]$} \\
\hline $\begin{array}{l}\text { Phyllanthus emblica } \\
\text { extract }\end{array}$ & Phyllanthus emblica & oxLDL, MDA & In vitro & {$[79]$} \\
\hline
\end{tabular}

TABLE 5: Chinese herbal compounds that suppress VSMC migration and proliferation.

\begin{tabular}{|c|c|c|c|c|}
\hline Compound & Herb & Target or indicator & Type of study & Reference \\
\hline $\begin{array}{l}\text { Protocatechuic } \\
\text { aldehyde }\end{array}$ & $\begin{array}{l}\text { Salvia miltiorrhiza } \\
\text { Bunge }\end{array}$ & PI3K/Akt, MAPK, cyclin D2 & In vitro & {$[93]$} \\
\hline $\begin{array}{l}\text { Gleditsia sinensis } \\
\text { thorn extract }\end{array}$ & $\begin{array}{l}\text { Gleditsia sinensis } \\
\text { thorns }\end{array}$ & $\begin{array}{l}\text { MMP-9; p21WAF1, cyclinB1, } \\
\text { Cdc2 and Cdc25c; ERK1/2, p38 } \\
\text { MAPK, JNK; NF- } \kappa \text { B, AP-1 }\end{array}$ & In vitro & {$[94]$} \\
\hline Corynoxeine & $\begin{array}{l}\text { Hook of Uncaria } \\
\text { rhynchophylla }\end{array}$ & $\begin{array}{l}\text { DNA synthesis of VSMCs, } \\
\text { ERK1/2 }\end{array}$ & In vivo & {$[95]$} \\
\hline $\begin{array}{l}\text { Phyllanthus emblica } \\
\text { extract }\end{array}$ & Phyllanthus emblica & ox-LDL, MDA & In vitro & {$[79]$} \\
\hline Berberine & Coptis chinensis & $\begin{array}{l}\text { MAPK1/2, ERK, Egr-1, PDGF, } \\
\text { c-Fos, Cyclin D1 }\end{array}$ & In vitro & {$[96]$} \\
\hline Nucifera leaf extract & $\begin{array}{l}\text { Nelumbo nucifera } \\
\text { GAERTN }\end{array}$ & $\begin{array}{l}\text { JNK, MAPK, FAK/PI } \\
\text { 3-kinase/small G protein }\end{array}$ & In vitro & {$[97]$} \\
\hline $\begin{array}{l}\text { Hibiscus sabdariffa } \\
\text { Extract }\end{array}$ & Hibiscus sabdariffa L. & $\begin{array}{l}\text { triglyceride, LDL, foam cell } \\
\text { formation, VSMC migration }\end{array}$ & In vivo & {$[98]$} \\
\hline $\begin{array}{l}\text { Panax notoginseng } \\
\text { saponins }\end{array}$ & Panax notoginseng & integrin, FAK, NF- $\kappa \mathrm{B}$ & In vivo & {$[99]$} \\
\hline $\begin{array}{l}\text { Astragalus } \\
\text { polysaccharide }\end{array}$ & $\begin{array}{l}\text { Astragalus } \\
\text { membranaceus }\end{array}$ & ABCA1, NF- $\kappa$ B & In vitro & {$[100]$} \\
\hline Scoparone & Artemisia scoparia & $\begin{array}{l}\text { monocyte adhesion, lipid laden } \\
\text { foam cells }\end{array}$ & In vivo & {$[87]$} \\
\hline $\begin{array}{l}\text { Hibiscus sabdariffa } \\
\text { Extract }\end{array}$ & Hibiscus sabdariffa L. & $\begin{array}{l}\text { TC, LDL-C; foam cell formation, } \\
\text { VSMC migration }\end{array}$ & In vivo & {$[98]$} \\
\hline
\end{tabular}


TABLE 6: Chinese herbal compounds that suppress foam cell formation.

\begin{tabular}{|c|c|c|c|c|}
\hline Compound & Herb & Target or indicator & Type of study & Reference \\
\hline $\begin{array}{l}\text { Panax notoginseng } \\
\text { saponins }\end{array}$ & Panax notoginseng & integrin, FAK, NF- $\kappa \mathrm{B}$ & In vivo & [99] \\
\hline $\begin{array}{l}\text { Astragalus } \\
\text { polysaccharide }\end{array}$ & $\begin{array}{l}\text { Astragalus } \\
\text { membranaceus }\end{array}$ & $\mathrm{ABCA}, \mathrm{NF}-\kappa \mathrm{B}$ & In vitro & {$[100]$} \\
\hline $\begin{array}{l}\text { Scoparone }(6,7- \\
\text { dimethoxycoumarin) }\end{array}$ & Artemisia scoparia & $\begin{array}{l}\text { monocyte adhesion, } \\
\text { lipid laden foam cells }\end{array}$ & In vivo & {$[87]$} \\
\hline $\begin{array}{l}\text { Hibiscus sabdariffa } \\
\text { Extract }\end{array}$ & Hibiscus sabdariffa L. & $\begin{array}{l}\text { TC, LDL-C; foam cell } \\
\text { formation, VSMC } \\
\text { migration }\end{array}$ & In vivo & {$[98]$} \\
\hline
\end{tabular}

Uncaria rhynchophylla, significantly inhibited the PDGFBB-induced DNA synthesis of VSMCs in a concentrationdependent manner without causing any cytotoxicity. Preincubation of VSMCs with corynoxeine significantly inhibited PDGF-BB-induced extracellular signal-regulated kinase 1/2 (ERK1/2) activation [95]. Liang et al. showed that Berberine, a compound from the Chinese herb Coptis chinensis, inhibited serum-stimulated rat aortic VSMC growth in a concentration-dependent manner. Berberine blocked injuryinduced VSMC regrowth by inactivation of the ERK/Egr1 signaling pathway thereby preventing the early signaling induced by injury in vitro [96].

3.5. Chinese Herb Compounds That Suppress Foam Cell Formation (Table 6). In the studies reported by Yuan et al., the formation of foam cells was inhibited by Panax notoginseng saponins (PNS) via its ability to inhibit the phosphorylation of FAK on threonine 397 and the translocation of NF- $\kappa \mathrm{B}$. Wang et al. discovered that TNF- $\alpha$ could enhance the activity of NF-kappa B in the foam cells, and this effect could be attenuated by Astragalus polysaccharide (APS), a compound derived from the Chinese herb Astragalus membranaceus [99]. In a study by Chen et al., large numbers of monocytes were found adherent to the luminal surface and a markedly thickened intima filled with many lipid laden foam cells was apparent. However when treated with Scoparone, a compound derived from the Chinese herb Artemisia scoparia, atherosclerosis was less advanced and the plasma cholesterol was lower [87]. Interestingly, Chen et al. reported that upon histopathological examination Hibiscus sabdariffa Extract (HSE) was noted to reduce foam cell formation and inhibit smooth muscle cell migration and calcification in the blood vessel of rabbits. These results clearly indicate that Chinese herb-derived extracts can be used to lower serum lipids and produce antiatherosclerotic activity [98].

3.6. Anti-Inflammatory Chinese Herb Compounds (Table 7). Intralesional or extralesional inflammation may hasten atheroma evolution and precipitate acute adverse events. Hence, herb-associated treatment targeting inflammation is beneficial. From the findings of Jia et al., real time RTPCR and Western blotting analysis revealed that Tanshinone IIA (TSN IIA) significantly decreased the expressions of the proapoptotic proteins Bax and caspase-3, significantly increased the expression of antiapoptotic protein Bcl-2, and resulted in the reduction of the Bax/Bcl-2 ratio in EA.hy926 cells induced by $\mathrm{H}_{2} \mathrm{O}_{2}$ [64]. Li et al. reported that Farrerol inhibited $\mathrm{H}_{2} \mathrm{O}_{2}$-induced elevation in the levels of intracellular malondialdehyde and ROS, as well as cell apoptosis [63]. Xing et al. found that LPS $(15 \mu \mathrm{g} / \mathrm{mL})$ stimulation for $30 \mathrm{hr}$ resulted in significant HUVEC apoptosis, as detected by Hoechst 33258 staining and Annexin V analysis and that Protocatechuic aldehyde (PCA, 0.25-1.0 mmol/L, $12 \mathrm{~h}$ ) inhibited the apoptosis in a dose-dependent manner [41].

Recently, the research of Napagoda et al. indicated that the ethnopharmacological use of Plectranthus zeylanicus extract constituted an anti-inflammatory remedy [101]. Zhang et al. found that Celastrus orbiculatus Thunb (COT) lowered the levels of C-reactive protein (CRP), interleukin-6 (IL6), and TNF- $\alpha$ in plasma [54]. Wang et al. discovered that Artemisinin, a compound derived from the Chinese herb Artemisia annua, inhibited the secretion and mRNA levels of TNF- $\alpha$, interleukin (IL)- $1 \beta$, and IL- 6 in a dose-dependent manner in THP-1 human monocytes. They also found that the NF- $\kappa$ B pathway may be involved in a decreased cytokine release [107]. Chen and Cheng reported that the extract from Chinese herb Feverfew effectively reduced LPS-mediated TNF- $\alpha$ and CCL2 (MCP-1) release by THP-1 cells [109].

\section{Summary and Perspective}

Herein, we have reviewed most of the Chinese herbal compounds recently reported to have antiatherogenic properties either in vitro or in vivo. Chinese herbal medicine has the potential to provide a major public health benefit by reducing morbidity and mortality secondary to cardiovascular disease. Recent experimental prevention and treatment studies using Chinese medicine clearly demonstrate the benefits of lowering LDL retention and LDL oxidant, protecting endothelium, inhibiting monocyte/macrophage/VSMC proliferation and migration, and preventing foam cell formation as well as the accompanying inflammation. While the promise of Chinese herb-derived compounds as effective therapies for atherosclerotic cardiovascular diseases has been indicated in the literature, the published studies have severe limitations and apparently more research is required. Firstly, most of the clinical studies are of limited value because of the small sample size and/or incomplete data and most experimental studies have focused mainly on single compounds extracted from Chinese herbs. Studies of Chinese 
TABLE 7: Anti-inflammatory Chinese herbal compounds.

\begin{tabular}{|c|c|c|c|c|}
\hline Compound & Herb & Target or indicator & Type of study & Reference \\
\hline $\begin{array}{l}\text { Plectranthus } \\
\text { zeylanicus extracts }\end{array}$ & $\begin{array}{l}\text { Plectranthus zeylanicus } \\
\text { Benth }\end{array}$ & $5-\mathrm{LO}$ & In vitro & {$[101]$} \\
\hline $\begin{array}{l}\text { Arisaema tortuosum } \\
\text { tuber extract }\end{array}$ & Arisaema tortuosum Schott & $\beta$-Glucuronidase; FRAP & In vitro & {$[61]$} \\
\hline $\begin{array}{l}\text { Prunella vulgaris } \\
\text { ethanol extract }\end{array}$ & Prunella vulgaris & $\begin{array}{l}\text { VCAM-1, ICAM-1, E-selectin, ROS; } \\
\text { p38 MAPK, ERK }\end{array}$ & In vitro & {$[91]$} \\
\hline $\begin{array}{l}\text { Celastrus orbiculatus } \\
\text { Thunb. }\end{array}$ & $\begin{array}{l}\text { Celastrus orbiculatus } \\
\text { Thunb. }\end{array}$ & $\begin{array}{l}\text { TC, non-HDL, TG, apoB100, apoE, } \\
\text { HDL; LDL receptor, SR-B1, CYP7A1, } \\
\text { HMGCR, CRP, MDA }\end{array}$ & In vivo & {$[54]$} \\
\hline $\begin{array}{l}2,3,5,4^{\prime} \text { - } \\
\text { Tetrahydroxystilbene- } \\
2 \text {-O- } \beta \text {-D-glucoside } \\
\text { (TSG) }\end{array}$ & Polygonum multiflorum & $\begin{array}{l}\text { HSP 70, lipocortin 1, Apo A-I; } \\
\text { calreticulin, vimentin; }\end{array}$ & In vivo & {$[102]$} \\
\hline Salvianolic acid B & Salvia miltiorrhiza Bunge & $\begin{array}{l}\text { JAK2 (Tyr 1007/1008), STAT1 (Tyr701 } \\
\text { and Ser727); CXC chemokines' IP-10, } \\
\text { Mig, I-TAC; monocyte adhesion; } \\
\text { PIAS1, SOCS1 }\end{array}$ & In vitro & {$[103]$} \\
\hline Cynanchum wilfordii & Cynanchum wilfordii & $\begin{array}{l}\text { LDL, HDL, NO, E-selectin, VCAM-1, } \\
\text { ICAM-1, ET-1 }\end{array}$ & In vivo & {$[40]$} \\
\hline $\begin{array}{l}\text { Panax notoginseng } \\
\text { extract }\end{array}$ & Panax notoginseng & TNF- $\alpha$, IL- 6 , TGF- $\beta$, IL-1 $\beta$ & In vivo & {$[104]$} \\
\hline Cryptotanshinone & Salvia miltiorrhiza Bunge & $\begin{array}{l}\text { oxLDL, NO, ICAM-1, VCAM-1; } \\
\text { monocyte adhesion }\end{array}$ & In vitro & {$[42]$} \\
\hline Salvianolic acid B & Salvia miltiorrhiza Bunge & $\begin{array}{l}\text { CD40, CD86, CD1a, HLA-DR; IL-12, } \\
\text { IL-10, TNF- } \alpha \text {; TLR4; PPAR } \gamma \text {; } \\
\text { p38-MAPK, PAI-1, JNK, NF- } \kappa \text { B, COX, } \\
\text { ERK1/2, prostaglandin E2, NADPH } \\
\text { oxidase, MMP-2, MMP-9, oxLDL, } \\
\text { ICAM-1, E-selectin }\end{array}$ & Both & $\begin{array}{l}{[53,71,72} \\
105,106]\end{array}$ \\
\hline Tanshinone IIA & Salvia miltiorrhiza Bunge & $\begin{array}{l}\text { oxLDL, monocyte adhesion, VSMC } \\
\text { migration and proliferation, } \\
\text { macrophage cholesterol accumulation, } \\
\text { TNF- } \alpha \text {, TGF- } \beta 1 \text {, platelet aggregation, } \\
\text { GPx }\end{array}$ & Both & {$[66,67]$} \\
\hline $\begin{array}{l}\text { Aqueous extract of } \\
\text { Buddleja officinalis }\end{array}$ & Buddleja officinalis & VCAM-1, ICAM-1; ROS; NF- $\kappa$ B & In vitro & {$[43]$} \\
\hline Artemisinin & Artemisia annua & $\begin{array}{l}\text { TNF- } \alpha \text {, IL-1ß, IL- } 6 \text {; NF- } \kappa \mathrm{B}, \mathrm{IKK} \alpha / \beta \\
\mathrm{I} \kappa \mathrm{B} \alpha\end{array}$ & In vitro & {$[107]$} \\
\hline Evodiamine & Evodia rutaecarpa & $\begin{array}{l}\text { COX-2, iNOS, prostaglandin E2; } \\
\text { HIF-1a; Akt, p70S6K, 4E-BP }\end{array}$ & In vitro & {$[108]$} \\
\hline Panax notoginseng & $\begin{array}{l}\text { Panax notoginseng } \\
\text { saponins }\end{array}$ & ICAM-1, VCAM-1 & In vivo & {$[45]$} \\
\hline Goji & $\begin{array}{l}\text { Lycium barbarum and } L . \\
\text { chinense }\end{array}$ & SOD, MDA; JNK & Both & {$[76]$} \\
\hline Ginkgo biloba extract & Ginkgo biloba & $\begin{array}{l}\text { VCAM-1, ICAM-1, E-selectin; ROS, } \\
\text { RSTF }\end{array}$ & Both & {$[46]$} \\
\hline $\begin{array}{l}\text { Scutellaria baicalensis } \\
\text { Georgi flavonoids }\end{array}$ & $\begin{array}{l}\text { Scutellaria baicalensis } \\
\text { Georgi }\end{array}$ & SOD & Both & {$[77]$} \\
\hline Emodin & Rheum rhabarbarum & ApoE, PPAR- $\gamma$, GM-CSF, MMP-9 & In vivo & {$[78]$} \\
\hline Bisacurone & $\begin{array}{l}\text { Curcuma longa Linne } \\
\text { (Zingiberaceae) }\end{array}$ & VCAM-1, NF- $\kappa$ B p65, Akt, PKC & In vitro & [49] \\
\hline Feverfew extract & Tanacetum parthenium & TNF- $\alpha$, CCL2 & In vitro & {$[109]$} \\
\hline Magnolol & Magnolia officinalis & $\begin{array}{l}\text { IL-6, STAT3, Tyr705 and Ser727, } \\
\text { ICAM-1, IREs, monocyte adhesion, } \\
\text { cyclin D1, MCP-1 }\end{array}$ & In vitro & {$[50]$} \\
\hline
\end{tabular}


TABLE 7: Continued.

\begin{tabular}{|c|c|c|c|c|}
\hline Compound & Herb & Target or indicator & Type of study & Reference \\
\hline Paeonol & Paeonia lactiflora Pallas & $\begin{array}{l}\text { ICAM-1, NF-kB p65 translocation, } \\
\text { ERK, p38 }\end{array}$ & In vitro & {$[81]$} \\
\hline $\begin{array}{l}\text { Aqueous extract of } \\
\text { Salvia miltiorrhiza }\end{array}$ & Salvia miltiorrhiza Bunge & ICAM-1, VCAM-1, GSH, NF-kB & In vitro & {$[52]$} \\
\hline Magnolol & Magnolia officinalis & MCP-1, NF- $\kappa$ B, VCAM-1 & In vivo & {$[51]$} \\
\hline Ginkgo biloba extract & Ginkgo biloba & VCAM-1, ICAM-1 & In vitro & [47] \\
\hline Scoparone & Artemisia scoparia & $\begin{array}{l}\text { monocyte adhesion, lipid laden foam } \\
\text { cells }\end{array}$ & In vivo & [87] \\
\hline Celastrol & $\begin{array}{l}\text { Tripterygium wilfordii } \\
\text { Hook F. }\end{array}$ & $\begin{array}{l}\text { oxLDL, LOX-1, ROS, iNOS, NO, } \\
\text { TNF- } \alpha \text {, IL-6 }\end{array}$ & In vivo & [89] \\
\hline
\end{tabular}

decoctions or formulations are scarce, although decoction and formulations are the main forms of therapy in traditional Chinese medicine practice. Capitalization of the interactions between the different components and herbs is the essence of traditional Chinese medicine whereby herbs are combined to attenuate toxicity as well as to enhance efficacy. Secondly, like other therapies, Chinese herbs and the compounds derived from them are expected to have side effects. However, published in vivo studies seldom mention whether adverse effects occurred. In future studies, including animal studies and clinical studies, systemic and organ-specific side effects of Chinese herb medicine should be carefully examined. Thirdly, in modern medical practice, it is unlikely that Chinese herbal medicine will be used as a sole treatment for cardiovascular disease; instead, they will more likely be used in combination with other proven drugs. Therefore, the herb-drug interaction should be carefully evaluated in future studies where Chinese herbs or compounds are used in addition to traditional proven therapies. Fourth, atherosclerosis is a multiple-staged and multifaceted disease; most published studies are focused on examining the effects of Chinese herb medicine on one or only a few aspects of the disease. In future studies, a more systemic evaluation of the effects of Chinese herbal medicine on all aspects of atherosclerosis should be performed, including lipoprotein metabolism, endothelial injury, systemic and arterial local inflammation, as well as cell apoptosis and efferocytosis dynamics/balance in the plaques.

\section{Abbreviations}

5-LO:
ABCA1:
AP-1:
ApoB100:
ApoE:
Cav-1:
CDC6:
COX:
CRP:
CYP7A1:
Egr-1:
ERK:

5-Lipoxygenase

ATP-binding cassette transporter A1

Activator protein-1

Apolipoprotein B100

Apolipoprotein E

Caveolin-1

Cell division cycle 6

Cyclooxygenase

C-Reactive protein

Cholesterol $7 \alpha$-hydroxylase A1

Early growth response protein 1

Extracellular-signal-regulated

kinase
E-selectin:

ET-1:

FRAP:

GM-CSF:

GPx:

GSH:

Hcy:

HGL:

HIF-1 $\alpha$ :

HMGCR:

ICAM-1:

IL:

iNOS:

IREs:

JNK:

KDR, or VEGF

receptor-2:

LDL:

LOX-1:

MAPK:

MCP-1:

MDA:

mLDL:

MMP:

NF- $\kappa$ B:

$\mathrm{NO}$ :

non-HDL:

OFR:

oxLDL:

PAI-1:

PDGF:

PI3K:

PPARs:

ROS:

RSTF:

SOD:
Endothelial cell selectin

Endothelin-1

Ferric reducing antioxidant power

Granulocyte-macrophage

colony-stimulating factor

Glutathione peroxidase

Intracellular glutathione

Homocysteine

High density lipoprotein

Hypoxia-inducible factor lalpha

3-Hydroxy-3-methyl-glutaryl-CoA

reductase

Intercellular cell adhesion

molecule-1

Interleukin

Inducible nitric oxide synthase

IL-6 response elements

c-Jun NH2-terminal kinase

Kinase insert domain receptor

Low density lipoprotein

Oxidized low density lipoprotein receptor-1

p38 mitogen-activated protein

kinase

Monocyte chemotactic protein-1

Malondialdehyde

Modified low density lipoprotein

Matrix metalloproteinase

Nuclear factor kappa B

Nitric oxide

Non-high-density lipoprotein

Oxygen-derived free radicals

Oxidized low-density lipoprotein

Plasminogen activator inhibitor

type 1

Platelet-derived growth factor

Phosphatidylinositol 3-kinase

Peroxisome proliferator-activated receptors

Reactive oxygen species

Redox-sensitive transcription

factor

Superoxide dismutase 
SR-B1: $\quad$ Scavenger receptor class B type 1

STAT3: $\quad$ Signal transducer and activator of transcription protein 3

TC: Total cholesterol

TG: Triglycerides

TNF- $\alpha$ : Tumor necrosis factor- $\alpha$

VCAM-1: $\quad$ Vascular cell adhesion molecule-1

VEGF: Vascular endothelial growth factor

VLDL: Very low density lipoprotein

VSMC: $\quad$ Vascular smooth muscle cell.

\section{Conflict of Interests}

The authors declare that they have no conflict of interests regarding the publication of this paper.

\section{Acknowledgment}

This work was supported by Grants from the National Institute of Health nos. R21AT006767 and R01HL116626 (to Daping Fan).

\section{References}

[1] W. Insull Jr., "The pathology of atherosclerosis: plaque development and plaque responses to medical treatment," The American Journal of Medicine, vol. 122, no. 1, pp. S3-S14, 2009.

[2] M. B. Furie and R. N. Mitchell, "Plaque attack: one hundred years of atherosclerosis in the American Journal of Pathology," The American Journal of Pathology, vol. 180, no. 6, pp. 2184-2187, 2012.

[3] P. Libby, P. M. Ridker, and A. Maseri, "Inflammation and atherosclerosis," Circulation, vol. 105, no. 9, pp. 1135-1143, 2002.

[4] N. Foin, P. Evans, and R. Krams, "Atherosclerosis: cell biology and lipoproteins-new developments in imaging of inflammation of the vulnerable plaque," Current Opinion in Lipidology, vol. 19, no. 1, pp. 98-100, 2008.

[5] A. Tavridou and V. G. Manolopoulos, "Novel molecules targeting dyslipidemia and atherosclerosis," Current Medicinal Chemistry, vol. 15, no. 8, pp. 792-802, 2008.

[6] D. Steinberg, "Thematic review series: the pathogenesis of atherosclerosis: an interpretive history of the cholesterol controversy, part III: mechanistically defining the role of hyperlipidemia," Journal of Lipid Research, vol. 46, no. 10, pp. 2037-2051, 2005.

[7] S. Omoigui, "Cholesterol synthesis is the trigger and isoprenoid dependent interleukin- 6 mediated inflammation is the common causative factor and therapeutic target for atherosclerotic vascular disease and age-related disorders including osteoporosis and type 2 diabetes," Medical Hypotheses, vol. 65, no. 3, pp. 559-569, 2005.

[8] K. J. Williams and I. Tabas, "Atherosclerosis and inflammation," Science, vol. 297, no. 5581, pp. 521-522, 2002.

[9] D. Steinberg, "An interpretive history of the cholesterol controversy. Part V. The discovery of the statins and the end of the controversy," Journal of Lipid Research, vol. 47, no. 7, pp. 13391351, 2006.
[10] R. B. Singh, S. A. Mengi, Y.-J. Xu, A. S. Arneja, and N. S. Dhalla, "Pathogenesis of atherosclerosis: a multifactorial process," Experimental and Clinical Cardiology, vol. 7, no. 1, pp. 4053, 2002.

[11] R. Ross, "Mechanisms of atherosclerosis-a review," Advances in Nephrology from the Necker Hospital, vol. 19, pp. 79-86, 1990.

[12] D. B. Cines, E. S. Pollak, C. A. Buck et al., "Endothelial cells in physiology and in the pathophysiology of vascular disorders," Blood, vol. 91, no. 10, pp. 3527-3561, 1998.

[13] P. Rajendran, T. Rengarajan, J. Thangavel et al., "The vascular endothelium and human diseases," International Journal of Biological Sciences, vol. 9, no. 10, pp. 1057-1069, 2013.

[14] L. Badimon, J. Martinez-Gonzalez, V. Llorente-Cortes, C. Rodriguez, and T. Padro, "Cell biology and lipoproteins in atherosclerosis," Current Molecular Medicine, vol. 6, no. 5, pp. 439-456, 2006.

[15] K. J. Williams and I. Tabas, "The response-to-retention hypothesis of early atherogenesis," Arteriosclerosis, Thrombosis, and Vascular Biology, vol. 15, no. 5, pp. 551-562, 1995.

[16] I. Peluso, G. Morabito, L. Urban, F. Ioannone, and M. Serafini, "Oxidative stress in atherosclerosis development: the central role of LDL and oxidative burst," Endocrine, Metabolic and Immune Disorders: Drug Targets, vol. 12, no. 4, pp. 351-360, 2012.

[17] J. Steinberger, S. R. Daniels, R. H. Eckel et al., "Progress and challenges in metabolic syndrome in children and adolescents: a scientific statement from the American Heart Association Atherosclerosis, Hypertension, and Obesity in the Young Committee of the Council on Cardiovascular Disease in the Young; Council on Cardiovascular Nursing; and Council on Nutrition, Physical Activity, and Metabolism," Circulation, vol. 119, no. 4, pp. 628-647, 2009.

[18] L. Badimón, G. Vilahur, and T. Padró, "Lipoproteins, platelets and atherothrombosis," Revista Espanola de Cardiologia, vol. 62, no. 10, pp. 1161-1178, 2009.

[19] K. Ley, Y. I. Miller, and C. C. Hedrick, "Monocyte and macrophage dynamics during atherogenesis," Arteriosclerosis, Thrombosis, and Vascular Biology, vol. 31, no. 7, pp. 1506-1516, 2011.

[20] P. Libby, "Inflammation in atherosclerosis," Arteriosclerosis, Thrombosis, and Vascular Biology, vol. 32, no. 9, pp. 2045-2051, 2012.

[21] D. Gomez and G. K. Owens, "Smooth muscle cell phenotypic switching in atherosclerosis," Cardiovascular Research, vol. 95, no. 2, pp. 156-164, 2012.

[22] P. Lacolley, V. Regnault, A. Nicoletti, Z. Li, and J.-B. Michel, “The vascular smooth muscle cell in arterial pathology: a cell that can take on multiple roles," Cardiovascular Research, vol. 95, no. 2, pp. 194-204, 2012.

[23] A. C. Doran, N. Meller, and C. A. McNamara, "Role of smooth muscle cells in the initiation and early progression of atherosclerosis," Arteriosclerosis, Thrombosis, and Vascular Biology, vol. 28, no. 5, pp. 812-819, 2008.

[24] M. Braun, P. Pietsch, K. Schrör, G. Baumann, and S. B. Felix, "Cellular adhesion molecules on vascular smooth muscle cells," Cardiovascular Research, vol. 41, no. 2, pp. 395-401, 1999.

[25] S. Ma, D. Yang, D. Li, B. Tang, and Y. Yang, "Oleic acid induces smooth muscle foam cell formation and enhances atherosclerotic lesion development via CD36," Lipids in Health and Disease, vol. 10, article 53, 2011.

[26] N. Platt, R. Haworth, L. Darley, and S. Gordon, “The many roles of the class A macrophage scavenger receptor," International Review of Cytology, vol. 212, pp. 1-40, 2002. 
[27] R. E. Clempus and K. K. Griendling, "Reactive oxygen species signaling in vascular smooth muscle cells," Cardiovascular Research, vol. 71, no. 2, pp. 216-225, 2006.

[28] L. Hegyi, J. N. Skepper, N. R. Cary, and M. J. Mitchinson, "Foam cell apoptosis and the development of the lipid core of human atherosclerosis," The Journal of Pathology, vol. 180, no. 4, pp. 423-429, 1996.

[29] B. L. Gerber, "In vivo evaluation of atherosclerotic plaque inflammation and of anti-inflammatory effects of statins by $18 \mathrm{~F}$ fluorodeoxyglucose positron emission tomography," Journal of the American College of Cardiology, vol. 62, no. 10, pp. 918-920, 2013.

[30] E. Thorp and I. Tabas, "Mechanisms and consequences of efferocytosis in advanced atherosclerosis," Journal of Leukocyte Biology, vol. 86, no. 5, pp. 1089-1095, 2009.

[31] R. R. S. Packard and P. Libby, "Inflammation in atherosclerosis: from vascular biology to biomarker discovery and risk prediction," Clinical Chemistry, vol. 54, no. 1, pp. 24-38, 2008.

[32] F. Grover-Paez and A. B. Zavalza-Gomez, "Endothelial dysfunction and cardiovascular risk factors," Diabetes Research and Clinical Practice, vol. 84, no. 1, pp. 1-10, 2009.

[33] R. Natarajan and Q. Cai, "Monocyte retention in the pathology of atherosclerosis," Future Cardiology, vol. 1, no. 3, pp. 331-340, 2005.

[34] H. Kanda, S. Tateya, Y. Tamori et al., "MCP-1 contributes to macrophage infiltration into adipose tissue, insulin resistance, and hepatic steatosis in obesity," The Journal of Clinical Investigation, vol. 116, no. 6, pp. 1494-1505, 2006.

[35] C. Zhang, "The role of inflammatory cytokines in endothelial dysfunction," Basic Research in Cardiology, vol. 103, no. 5, pp. 398-406, 2008.

[36] E. Galkina and K. Ley, "Immune and inflammatory mechanisms of atherosclerosis," Annual Review of Immunology, vol. 27, pp. 165-197, 2009.

[37] P. Libby, "Inflammation in atherosclerosis," Nature, vol. 420, no. 6917, pp. 868-874, 2002.

[38] P. Libby, "Molecular and cellular mechanisms of the thrombotic complications of atherosclerosis," The Journal of Lipid Research, vol. 50, pp. S352-S357, 2009.

[39] C. Tian, R. Zhang, X. Ye et al., "Resveratrol ameliorates highglucose-induced hyperpermeability mediated by caveolae via VEGF/KDR pathway," Genes and Nutrition, vol. 8, no. 2, pp. 231239, 2013.

[40] D. H. Choi, Y. J. Lee, H. C. Oh et al., "Improved endothelial dysfunction by Cynanchum wilfordii in Apolipoprotein $\mathrm{E}^{-/-}$ mice fed a high fat/cholesterol diet," Journal of Medicinal Food, vol. 15, no. 2, pp. 169-179, 2012.

[41] Y.-L. Xing, Z. Zhou, Z.-Y. Zhong et al., "Protocatechuic aldehyde inhibits lipopolysaccharide-induced human umbilical vein endothelial cell apoptosis via regulation of caspase-3," Phytotherapy Research, vol. 26, no. 9, pp. 1334-1341, 2012.

[42] K.-P. Ang, H.-K. Tan, M. Selvaraja et al., "Cryptotanshinone attenuates in vitro oxLDL-induced pre-lesional atherosclerotic events," Planta Medica, vol. 77, no. 16, pp. 1782-1787, 2011.

[43] Y. J. Lee, M. K. Moon, S. M. Hwang et al., "Anti-inflammatory effect of buddleja officinalis on vascular inflammation in human umbilical vein endothelial cells," The American Journal of Chinese Medicine, vol. 38, no. 3, pp. 585-598, 2010.

[44] M. A. Altug Tuncer, B. Yaymaci, L. Sati et al., "Influence of Tribulus terrestris extract on lipid profile and endothelial structure in developing atherosclerotic lesions in the aorta of rabbits on a high-cholesterol diet," Acta Histochemica, vol. 111, no. 6, pp. 488-500, 2009.

[45] J.-B. Wan, S. M.-Y. Lee, J.-D. Wang et al., "Panax notoginseng reduces atherosclerotic lesions in ApoE-deficient mice and inhibits TNF- $\alpha$-induced endothelial adhesion molecule expression and monocyte adhesion," Journal of Agricultural and Food Chemistry, vol. 57, no. 15, pp. 6692-6697, 2009.

[46] Y.-H. Chen, S.-J. Lin, Y.-L. Chen, P.-L. Liu, and J.-W. Chen, "Anti-inflammatory effects of different drugs/agents with antioxidant property on endothelial expression of adhesion molecules," Cardiovascular and Hematological Disorders-Drug Targets, vol. 6, no. 4, pp. 279-304, 2006.

[47] J.-W. Chen, Y.-H. Chen, F.-Y. Lin, Y.-L. Chen, and S.-J. Lin, "Ginkgo biloba extract inhibits tumor necrosis factor- $\alpha$-induced reactive oxygen species generation, transcription factor activation, and cell adhesion molecule expression in human aortic endothelial cells," Arteriosclerosis, Thrombosis, and Vascular Biology, vol. 23, no. 9, pp. 1559-1566, 2003.

[48] K. Steinkamp-Fenske, L. Bollinger, N. Völler et al., "Ursolic acid from the Chinese herb Danshen (Salvia miltiorrhiza L.) upregulates eNOS and downregulates Nox4 expression in human endothelial cells," Atherosclerosis, vol. 195, no. 1, pp. e104-e111, 2007.

[49] D.-I. Sun, I. T. Nizamutdinova, Y. M. Kim et al., "Bisacurone inhibits adhesion of inflammatory monocytes or cancer cells to endothelial cells through down-regulation of VCAM-1 expression," International Immunopharmacology, vol. 8, no. 9, pp. 1272-1281, 2008.

[50] S.-C. Chen, Y.-L. Chang, D. L. Wang, and J.-J. Cheng, "Herbal remedy magnolol suppresses IL-6-induced STAT3 activation and gene expression in endothelial cells," British Journal of Pharmacology, vol. 148, no. 2, pp. 226-232, 2006.

[51] Y.-H. Chen, S.-J. Lin, J.-W. Chen, H.-H. Ku, and Y.-L. Chen, "Magnolol attenuates VCAM-1 expression in vitro in TNF- $\alpha$ treated human aortic endothelial cells and in vivo in the aorta of cholesterol-fed rabbits," British Journal of Pharmacology, vol. 135, no. 1, pp. 37-47, 2002.

[52] M. Ding, G.-R. Zhao, Y.-J. Yuan, and Z.-X. Guo, "Aqueous extract of Salvia miltiorrhoza regulates adhesion molecule expression of tumor necrosis factor $\alpha$-induced endothelial cells by blocking activation of nuclear factor $\kappa \mathrm{B}$," Journal of Cardiovascular Pharmacology, vol. 45, no. 6, pp. 516-524, 2005.

[53] Y.-H. Chen, S.-J. Lin, H.-H. Ku et al., "Salvianolic acid B attenuates VCAM-1 and ICAM-1 expression in TNF- $\alpha$-treated human aortic endothelial cells," Journal of Cellular Biochemistry, vol. 82, no. 3, pp. 512-521, 2001.

[54] Y. Zhang, Y. Si, S. Yao et al., "Celastrus orbiculatus thunb. decreases athero-susceptibility in lipoproteins and the aorta of Guinea pigs fed high fat diet," Lipids, vol. 48, no. 6, pp. 619-631, 2013.

[55] Y. Bao, L. Wang, Y. Xu et al., "Salvianolic acid B inhibits macrophage uptake of modified low density lipoprotein (mLDL) in a scavenger receptor CD36-dependent manner," Atherosclerosis, vol. 223, no. 1, pp. 152-159, 2012.

[56] D. H. Choi, Y. J. Lee, J. S. Kim, D. G. Kang, and H. S. Lee, "Cynanchum wilfordii ameliorates hypertension and endothelial dysfunction in rats fed with high fat/cholesterol diets," Immunopharmacology and Immunotoxicology, vol. 34, no. 1, pp. 4-11, 2012.

[57] S. Subramaniam, R. Subramaniam, S. Rajapandian, S. Uthrapathi, V. R. Gnanamanickam, and G. P. Dubey, "Anti-atherogenic activity of ethanolic fraction of terminalia arjuna bark on 
hypercholesterolemic rabbits," Evidence-Based Complementary and Alternative Medicine, vol. 2011, Article ID 487916, 8 pages, 2011.

[58] N. J. Dinani, S. Asgary, H. Madani, G. H. Naderi, and P. Mahzoni, "Hypocholesterolemic and antiatherosclerotic effect of Artemisia aucheri in hypercholesterolemic rabbits," Pakistan Journal of Pharmaceutical Sciences, vol. 23, no. 3, pp. 321-325, 2010.

[59] H.-X. Ni, N.-J. Yu, and X.-H. Yang, “The study of ginsenoside on PPAR $\gamma$ expression of mononuclear macrophage in type 2 diabetes," Molecular Biology Reports, vol. 37, no. 6, pp. 29752979, 2010.

[60] S. Amrani, H. Harnafi, N. E. H. Bouanani et al., "Hypolipidaemic activity of aqueous Ocimum basilicum extract in acute hyperlipidaemia induced by triton WR-1339 in rats and its antioxidant property," Phytotherapy Research, vol. 20, no. 12, pp. 1040-1045, 2006.

[61] S. H. Nile and S. W. Park, "HPTLC analysis, antioxidant, anti-inflammatory and antiproliferative activities of Arisaema tortuosum tuber extract," Pharmaceutical Biology, vol. 52, no. 2, pp. 221-227, 2014.

[62] S. Pandeti, R. Sonkar, A. Shukla, G. Bhatia, and N. Tadigoppula, "Synthesis of new andrographolide derivatives and evaluation of their antidyslipidemic, LDL-oxidation and antioxidant activity," European Journal of Medicinal Chemistry, vol. 69, pp. 439448, 2013.

[63] J.-K. Li, R. Ge, L. Tang, and Q.-S. Li, "Protective effects of farrerol against hydrogen-peroxide-induced apoptosis in human endothelium-derived EA.hy926 cells," Canadian Journal of Physiology and Pharmacology, vol. 91, no. 9, pp. 733-740, 2013.

[64] L.-Q. Jia, G.-L. Yang, L. Ren et al., “Tanshinone IIA reduces apoptosis induced by hydrogen peroxide in the human endothelium-derived EA.hy926 cells," Journal of Ethnopharmacology, vol. 143, no. 1, pp. 100-108, 2012.

[65] S. Xu, Z. Liu, Y. Huang et al., "Tanshinone II-A inhibits oxidized LDL-induced LOX-1 expression in macrophages by reducing intracellular superoxide radical generation and NF- $\kappa \mathrm{B}$ activation," Translational Research, vol. 160, no. 2, pp. 114-124, 2012.

[66] S. Gao, Z. Liu, H. Li, P. J. Little, P. Liu, and S. Xu, "Cardiovascular actions and therapeutic potential of tanshinone IIA," Atherosclerosis, vol. 220, no. 1, pp. 3-10, 2012.

[67] Y.-I. Li, G. Elmer, and R. C. LeBoeuf, “Tanshinone IIA reduces macrophage death induced by hydrogen peroxide by upregulating glutathione peroxidase," Life Sciences, vol. 83, no. 15-16, pp. 557-562, 2008.

[68] Y.-C. Hung, P.-W. Wang, and T.-L. Pan, "Functional proteomics reveal the effect of Salvia miltiorrhiza aqueous extract against vascular atherosclerotic lesions," Biochimica et Biophysica Acta: Proteins and Proteomics, vol. 1804, no. 6, pp. 1310-1321, 2010.

[69] N. P. Visavadiya, B. Soni, N. Dalwadi, and D. Madamwar, "Chlorophytum borivilianum as potential terminator of free radicals in various in vitro oxidation systems," Drug and Chemical Toxicology, vol. 33, no. 2, pp. 173-182, 2010.

[70] T.-L. Yang, F.-Y. Lin, Y.-H. Chen et al., "Salvianolic acid $\mathrm{B}$ inhibits low-density lipoprotein oxidation and neointimal hyperplasia in endothelium-denuded hypercholesterolaemic rabbits," Journal of the Science of Food and Agriculture, vol. 91, no. 1, pp. 134-141, 2011.

[71] Y.-L. Chen, C.-S. Hu, F.-Y. Lin et al., "Salvianolic acid B attenuates cyclooxygenase-2 expression in vitro in LPS-treated human aortic smooth muscle cells and in vivo in the apolipoprotein-Edeficient mouse aorta," Journal of Cellular Biochemistry, vol. 98, no. 3, pp. 618-631, 2006.

[72] S. J. Lin, I. T. Lee, Y. H. Chen et al., "Salvianolic acid B attenuates MMP-2 and MMP-9 expression in vivo in apolipoprotein-Edeficient mouse aorta and in vitro in LPS-treated human aortic smooth muscle cells," Journal of Cellular Biochemistry, vol. 100, no. 2, pp. 372-384, 2007.

[73] Y.-J. Wu, C.-Y. Hong, S.-J. Lin, P. Wu, and M.-S. Shiao, "Increase of vitamin e content in LDL and reduction of atherosclerosis in cholesterol-fed rabbits by a water-soluble antioxidant-rich fraction of Salvia miltiorrhiza," Arteriosclerosis, Thrombosis, and Vascular Biology, vol. 18, no. 3, pp. 481-486, 1998.

[74] H.-J. Park, "Chemistry and pharmacological action of caffeoylquinic acid derivatives and pharmaceutical utilization of chwinamul (Korean Mountainous Vegetable)," Archives of Pharmacal Research, vol. 33, no. 11, pp. 1703-1720, 2010.

[75] H. Ma, X. He, Y. Yang, M. Li, D. Hao, and Z. Jia, "The genus Epimedium: an ethnopharmacological and phytochemical review," Journal of Ethnopharmacology, vol. 134, no. 3, pp. 519-541, 2011.

[76] O. Potterat, "Goji (Lycium barbarum and L. chinense): phytochemistry, pharmacology and safety in the perspective of traditional uses and recent popularity," Planta Medica, vol. 76, no. 1, pp. 7-19, 2010.

[77] M. Broncel, "Antiatherosclerotic properties of flavones from the roots of Scutellaria baicalensis Georgi," Wiadomości Lekarskie, vol. 60, no. 5-6, pp. 294-297, 2007.

[78] M. Zhou, H. Xu, L. Pan, J. Wen, Y. Guo, and K. Chen, "Emodin promotes atherosclerotic plaque stability in fat-fed apolipoprotein E-deficient mice," Tohoku Journal of Experimental Medicine, vol. 215, no. 1, pp. 61-69, 2008.

[79] W. Duan, Y. Yu, and L. Zhang, "Antiatherogenic effects of Phyllanthus Emblica associated with corilagin and its analogue," Yakugaku Zasshi, vol. 125, no. 7, pp. 587-591, 2005.

[80] M.-J. Wu, C.-L. Huang, T.-W. Lian, M.-C. Kou, and L. Wang, "Antioxidant activity of Glossogyne tenuifolia," Journal of Agricultural and Food Chemistry, vol. 53, no. 16, pp. 6305-6312, 2005.

[81] I. T. Nizamutdinova, H. M. Oh, Y. N. Min et al., "Paeonol suppresses intercellular adhesion molecule-1 expression in tumor necrosis factor- $\alpha$-stimulated human umbilical vein endothelial cells by blocking p38, ERK and nuclear factor- $\kappa \mathrm{B}$ signaling pathways," International Immunopharmacology, vol. 7, no. 3, pp. 343-350, 2007.

[82] A. Gugliucci and T. Menini, "Three different pathways for human LDL oxidation are inhibited in vitro by water extracts of the medicinal herb Achyrocline satureoides," Life Sciences, vol. 71, no. 6, pp. 693-705, 2002.

[83] T. H. Park, D. H. Kim, C. H. Kim et al., "Peroxynitrite scavenging mode of alaternin isolated from Cassia tora," Journal of Pharmacy and Pharmacology, vol. 56, no. 10, pp. 1315-1321, 2004.

[84] K. Chan, S. H. Chui, D. Y. L. Wong, W. Y. Ha, C. L. Chan, and R. N. S. Wong, "Protective effects of Danshensu from the aqueous extract of Salvia miltiorrhiza (Danshen) against homocysteineinduced endothelial dysfunction," Life Sciences, vol. 75, no. 26, pp. 3157-3171, 2004.

[85] L. Li, L.-P. Jiao, and B. H. Lau, "Protective effect of gypenosides against oxidative stress in phagocytes, vascular endothelial cells and liver microsomes," Cancer Biotherapy, vol. 8, no. 3, pp. 263272, 1993. 
[86] H.-C. Huang, H.-R. Wang, and L.-M. Hsieh, "Antiproliferative effect of baicalein, a flavonoid from a Chinese herb, on vascular smooth muscle cell," European Journal of Pharmacology, vol. 251, no. 1, pp. 91-93, 1994.

[87] Y.-L. Chen, H.-C. Huang, Y.-I. Weng, Y.-J. Yu, and Y.-T. Lee, "Morphological evidence for the antiatherogenic effect of scoparone in hyperlipidaemic diabetic rabbits," Cardiovascular Research, vol. 28, no. 11, pp. 1679-1685, 1994.

[88] P. Chan and B. Tomlinson, "Antioxidant effects of Chinese traditional medicine: focus on trilinolein isolated from the Chinese herb sanchi (Panax pseudoginseng)," The Journal of Clinical Pharmacology, vol. 40, no. 5, pp. 457-461, 2000.

[89] L. Gu, W. Bai, S. Li et al., "Celastrol prevents atherosclerosis via inhibiting LOX-1 and oxidative stress," PLoS ONE, vol. 8, no. 6, Article ID e65477, 2013.

[90] M. F. Andreasen, A.-K. Landbo, L. P. Christensen, A. Hansen, and A. S. Meyer, "Antioxidant effects of phenolic rye (Secale cereale L.) extracts, monomeric hydroxycinnamates, and ferulic acid dehydrodimers on human low-density lipoproteins," Journal of Agricultural and Food Chemistry, vol. 49, no. 8, pp. 40904096, 2001.

[91] S. H. Park, H. J. Koo, Y. Y. Sung, and H. K. Kim, "The protective effect of Prunella vulgaris ethanol extract against vascular inflammation in TNF- $\alpha$-stimulated human aortic smooth muscle cells," BMB Reports, vol. 46, no. 7, pp. 352-357, 2013.

[92] F. Wang, Q. Gao, S. Guo et al., "The sonodynamic effect of curcumin on THP-1 cell-derived macrophages," BioMed Research International, vol. 2013, Article ID 737264, 9 pages, 2013.

[93] C. Y. Moon, C. R. Ku, Y. H. Cho, and E. J. Lee, "Protocatechuic aldehyde inhibits migration and proliferation of vascular smooth muscle cells and intravascular thrombosis," Biochemical and Biophysical Research Communications, vol. 423, no. 1, pp. 116-121, 2012.

[94] S.-J. Lee, S.-S. Park, W.-J. Kim, and S.-K. Moon, "Gleditsia sinensis thorn extract inhibits proliferation and TNF- $\alpha$-induced MMP-9 expression in vascular smooth muscle cells," The American Journal of Chinese Medicine, vol. 40, no. 2, pp. 373386, 2012.

[95] T.-J. Kim, J.-H. Lee, J.-J. Lee et al., "Corynoxeine isolated from the hook of Uncaria rhynchophylla inhibits rat aortic vascular smooth muscle cell proliferation through the blocking of extracellular signal regulated kinase 1/2 phosphorylation," Biological and Pharmaceutical Bulletin, vol. 31, no. 11, pp. 20732078, 2008.

[96] K.-W. Liang, C.-T. Ting, S.-C. Yin et al., "Berberine suppresses MEK/ERK-dependent Egr-1 signaling pathway and inhibits vascular smooth muscle cell regrowth after in vitro mechanical injury," Biochemical Pharmacology, vol. 71, no. 6, pp. 806-817, 2006.

[97] H. H. Ho, L. S. Hsu, K. C. Chan, H. M. Chen, C. H. Wu, and C. J. Wang, "Extract from the leaf of nucifera reduced the development of atherosclerosis via inhibition of vascular smooth muscle cell proliferation and migration," Food and Chemical Toxicology, vol. 48, no. 1, pp. 159-168, 2010.

[98] C.-C. Chen, J.-D. Hsu, S.-F. Wang et al., "Hibiscus sabdariffa extract inhibits the development of atherosclerosis in cholesterol-fed rabbits," Journal of Agricultural and Food Chemistry, vol. 51, no. 18, pp. 5472-5477, 2003.

[99] Z. Yuan, Y. Liao, G. Tian et al., "Panax notoginseng saponins inhibit Zymosan A induced atherosclerosis by suppressing integrin expression, FAK activation and NF- $\kappa$ B translocation," Journal of Ethnopharmacology, vol. 138, no. 1, pp. 150-155, 2011.

[100] Y.-F. Wang, X.-F. Yang, B. Cheng et al., "Protective effect of astragalus polysaccharides on ATP binding cassette transporter A1 in THP-1 derived foam cells exposed to tumor necrosis factor-alpha," Phytotherapy Research, vol. 24, no. 3, pp. 393-398, 2010.

[101] M. Napagoda, J. Gerstmeier, S. Wesely et al., "Inhibition of 5-lipoxygenase as anti-inflammatory mode of action of Plectranthus zeylanicus Benth and chemical characterization of ingredients by a mass spectrometric approach," Journal of Ethnopharmacology, vol. 151, no. 2, pp. 800-809, 2014.

[102] W. Yao, W. Fan, C. Huang, H. Zhong, X. Chen, and W. Zhang, "Proteomic analysis for anti-atherosclerotic effect of tetrahydroxystilbene glucoside in rats," Biomedicine \& Pharmacotherapy, vol. 67, no. 2, pp. 140-145, 2013.

[103] S. C. Chen, Y. L. Lin, B. Huang, D. L. Wang, and J. J. Cheng, "Salvianolic acid B suppresses IFN- $\gamma$-induced JAK/STAT1 activation in endothelial cells," Thrombosis Research, vol. 128, no. 6, pp. 560-564, 2011.

[104] K. D. Tsai, S. M. Yang, J. C. Lee et al., "Panax notoginseng attenuates bleomycin-induced pulmonary fibrosis in mice," Evidence-Based Complementary and Alternative Medicine, vol. 2011, Article ID 404761, 7 pages, 2011.

[105] A. Sun, H. Liu, S. Wang et al., "Salvianolic acid B suppresses maturation of human monocyte-derived dendritic cells by activating PPARy," British Journal of Pharmacology, vol. 164, no. 8, pp. 2042-2053, 2011.

[106] Z. Zhou, Y. Liu, A.-D. Miao, and S.-Q. Wang, "Salvianolic acid B attenuates plasminogen activator inhibitor type 1 production in TNF- $\alpha$ treated human umbilical vein endothelial cells," Journal of Cellular Biochemistry, vol. 96, no. 1, pp. 109-116, 2005.

[107] Y. Wang, Z. Huang, L. Wang et al., "The anti-malarial artemisinin inhibits pro-inflammatory cytokines via the NF$\kappa \mathrm{B}$ canonical signaling pathway in PMA-induced THP-1 monocytes," International Journal of Molecular Medicine, vol. 27, no. 2, pp. 233-241, 2011.

[108] Y.-N. Liu, S.-L. Pan, C.-H. Liao et al., "Evodiamine represses hypoxia-induced inflammatory proteins expression and hypoxia-inducible factor $1 \alpha$ accumulation in RAW264.7," Shock, vol. 32, no. 3, pp. 263-269, 2009.

[109] C.-F. Chen and C.-H. Cheng, "Regulation of cellular metabolism and cytokines by the medicinal herb feverfew in the human monocytic THP-1 cells," Evidence-Based Complementary and Alternative Medicine, vol. 6, no. 1, pp. 91-98, 2009. 


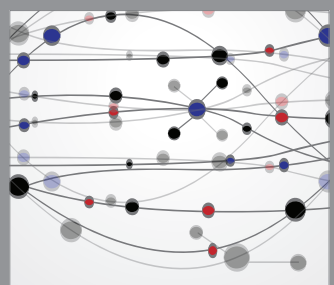

The Scientific World Journal
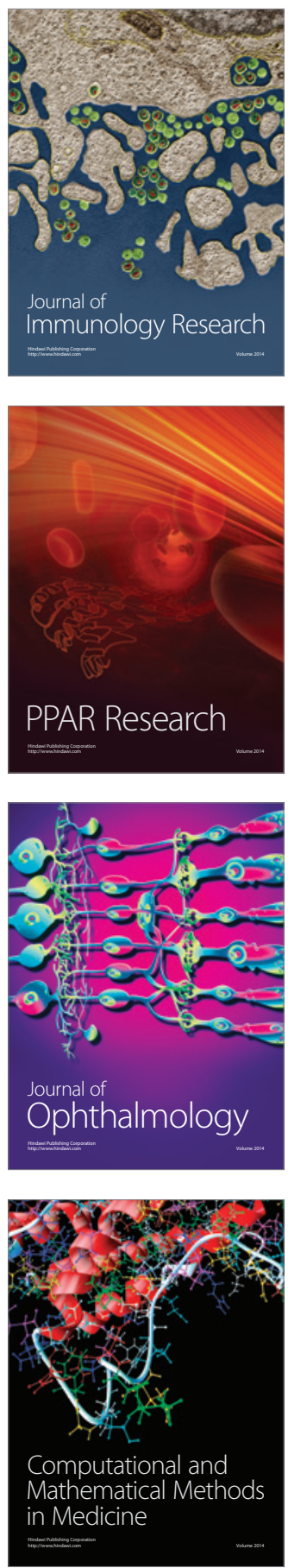

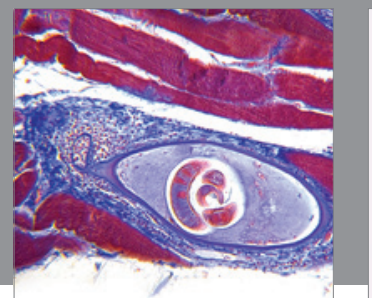

Gastroenterology

Research and Practice
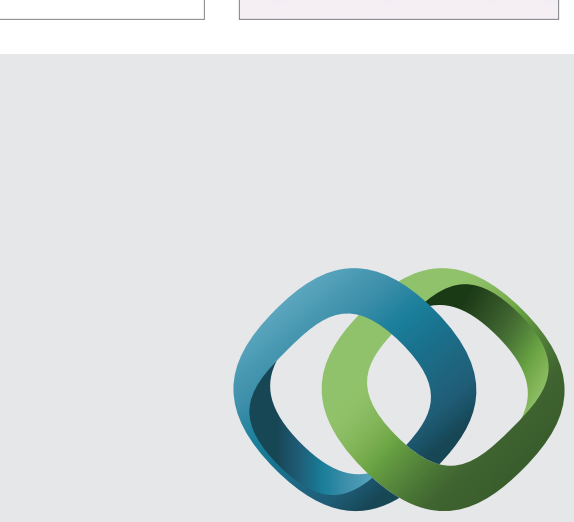

\section{Hindawi}

Submit your manuscripts at

http://www.hindawi.com
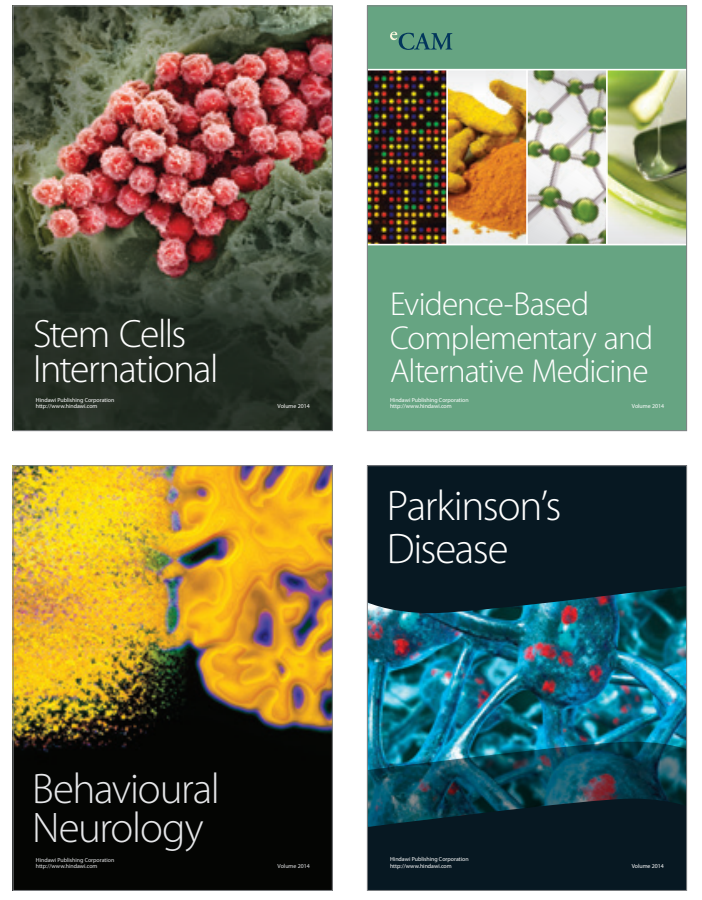
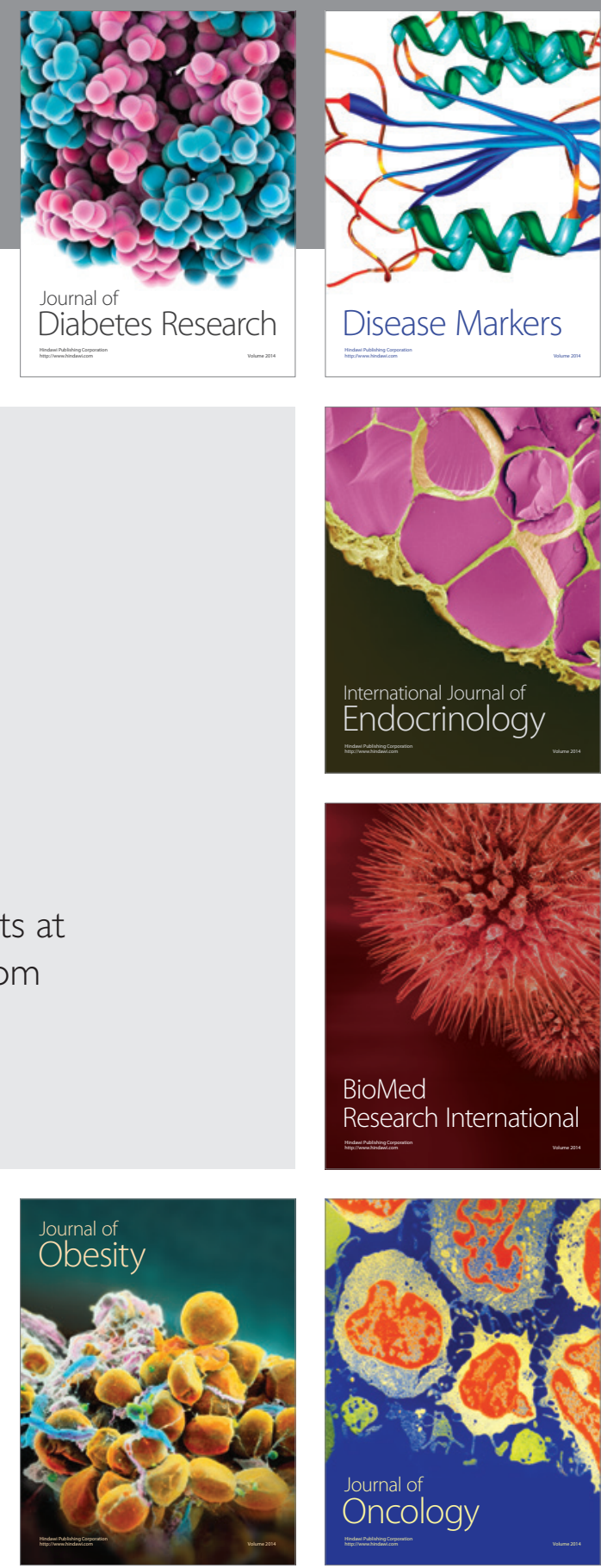

Disease Markers
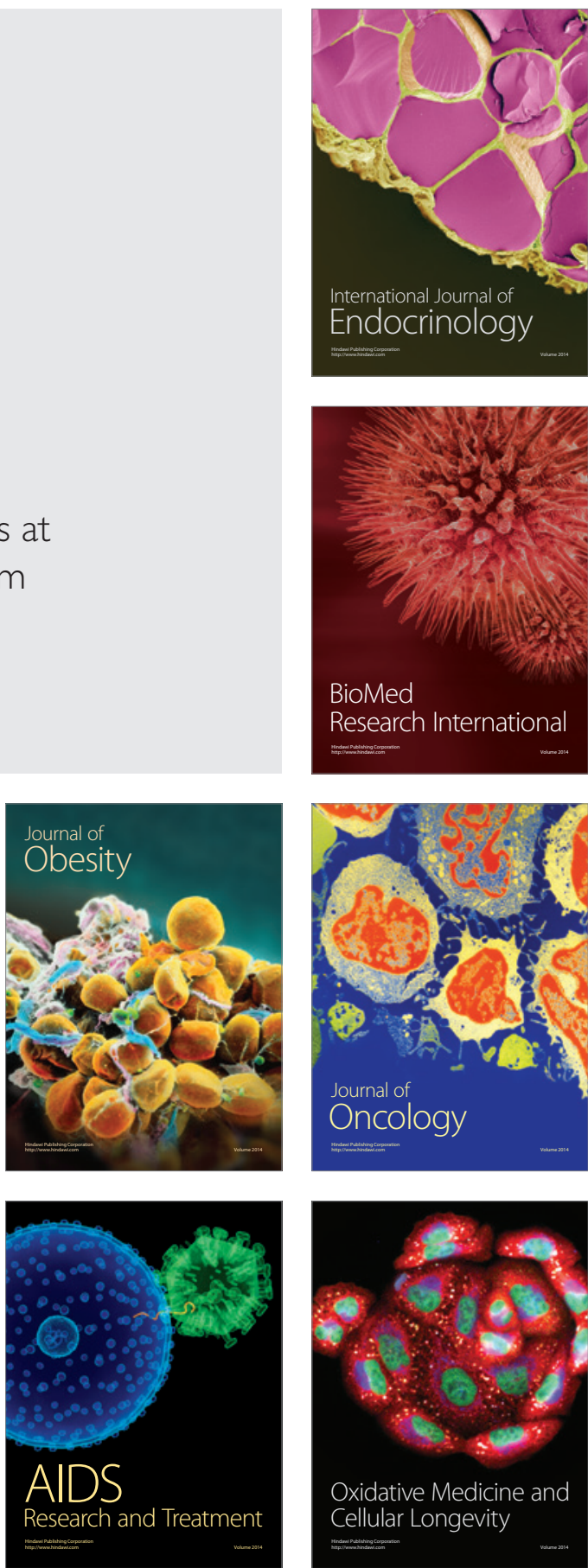